University of Louisville

ThinkIR: The University of Louisville's Institutional Repository

1946

\title{
A study of the trends and issues in the administration of mentally- retarded children in the elementary schools in a series of cities.
}

Elizabeth Veronica Sullivan

University of Louisville

Follow this and additional works at: https://ir.library.louisville.edu/etd

Part of the Education Commons

\section{Recommended Citation}

Sullivan, Elizabeth Veronica, "A study of the trends and issues in the administration of mentally-retarded children in the elementary schools in a series of cities." (1946). Electronic Theses and Dissertations.

Paper 2181.

https://doi.org/10.18297/etd/2181

This Master's Thesis is brought to you for free and open access by ThinkIR: The University of Louisville's Institutional Repository. It has been accepted for inclusion in Electronic Theses and Dissertations by an authorized administrator of ThinkIR: The University of Louisville's Institutional Repository. This title appears here courtesy of the author, who has retained all other copyrights. For more information, please contact thinkir@louisville.edu. 


\title{
UNIVBRSITY OF LOUISVILIJ
}

A Study of the Trends and Issues in the Administration of Mentally-Retarded Children in the Rementary Schools in a Series of Cities

\author{
A Dissertation \\ Submitted to the Feculty \\ Of the Graduate School of the University of Louisville \\ In Partial Fulfiliment of the \\ Requirements for the Degreo \\ Of Master of Arts
}

Department of Education

By

Alizaboth Verontca Sullivan

Year

1946 
NME OF STUDEN : Plizeboth Veronice Sullivan

TITLE OF THESIS: A Study of the Tronds and Issues

in the Administration of Mentelly =

Retarded Children in the lemen-

tary Schools in a Sertes of Citios

APPROVED BY READING COMMTTTTHE COMPOSED OF THE FOLLOTING MGLBRRS :

Charles R. Ackerman

John Dotson

NAME OF DIRECTCR: _ J. J. Oppenheimer

DATE : August 32, 1946. 
A STUDY OF THE TRENDS AND ISSUES IN THE ADMINISTRATION OF MENT ALLY-RETARDND CHILDREN IN THE BLEMANTARY

SCHOOLS IN A SERIES OF CIIIFS

$$
33934
$$




\section{TABLE OP CONTENTS}

GHAPTTR

PAGE

I The Need of the study................... I

II A survey of Related Information........... 11

Part I. Identification of the MentallyRetarded................... 11

Part II. The Problem of Administration....... 27

III A study of the Ungraded Classes in the rementary Schools of Louisvillo............ 42

IV Findings of the Questionnaire............ 58

$\checkmark$ A Summary of the Issues Involved and some Suggestions.......................... 85

vI $\quad$ Bibliography...................... 94

Appendix........................... 98 


\section{LIST OF TABLES}

TABLX

Page

I Types of Puplls Admitted to Special or

Ungradod Classes in the Elementary Schools..... 62

II Method of Selection of Children for Placement

in Special or Ungraded Classes.............. 64

III Information Roquired to be Known of a Child

Before Admittance to Special Classes.......... 66

IV Housing Arrengement in the Hementary school

for Special or Ungraded Classes.............. 68

$v$ Duties of the Supervisor of Ungraded or Special

Classes................................

$\mathbf{7}$

VI Information Desired Regarding the Curriculum of Special or Ungraded Classes for Mentally-

Reterded Children.......................

VII Instructional Methods Osed in Speciel or

Ungraded Classes....................... 


\section{LIST OF CHARTS}

CHART

I Percent of School systems that Require Specielly

Trained Teachers for Ungraded or Special

Classes................................. 69

II Percent of School systems That Require Specielly

Trained Supervisors for Ungraded or Special

Classes............................... 70

II Percent of Cities that Have a Definite Plan of

Curriculum........................... 73

IV Percent of Schools Using the Maximum Number of Pupils per Teacher in Ungraded or Special Classes 78

$v$ Percent of Cities that Have a Follow-Up Plan for the Mentelly-Retarded Pupll After He Leaves

school............................... 80 
CHAPTER I

THE NRED OF A STUDY 


\section{INTRODUCTION}

It is an accepted American principle that we must provide oqual oducational opportunities for ell children. Individual differences must be recognized and provisions should be made to properly care for them. Some children have problems so serious that they noed spectal help to develop their capacities and overcome their limitations. Among this eroup of ch1ldren with exceptionel problems needing speciel help are found the mentally handicapped or subnormal mental child. In many cities throughout the United States there have been establishod special clesses to take care of those tho deviate from tho normal, mentally and socially.

It hes been more then seventy-five years since the first special des cless for handicapped children was organizod by a local public school system in the United States. Speciel education for children with special problems is now part and parcel of the modern educational progrem. Now tasks ahead consist not so much in developing a philosophy or initiating a progren but rather in finding more effective ways for exdsting philosophy and progrem to reach all children in need. Wartime conditions have accentuated the problems of exceptionel children. Post-war developments should stress suitable adaptations in every comminity to meet those problems."I

As a teacher of one of these special classes for mentelly handicapped chlldren. the wrlter has a profound interest in all matters that concern the development of these exceptional children in their training that rould expand their ability to lead a bappy and successfur 11 fe.

For the pest eight jears the writer has been a teacher of an ungraded class in the elementary schools of Louisville. Since the school

1 Martens, Elise H., Men Tasks in the Education of Exceptional Children" National Educational Journal, May, 1946. p. 239. 
has only one of these special clesses, the membership of the class includes children socially maladjusted as well as academically retarded and mentelly retarded children. The ages of the children cover a span of from elght to sixteen jears with a varied state of mental ability. Therefore, the witer belleves that if the class is to provide the right opportunity for each individual child a thorough knorledge of the significance of ungraded classes should be studied. The writer realizes that there will be many conflicting thoughts and probably no definite conclusions of what the Ideal situation should involve, but feels that the study of the trends and lasues involved in the care of the mentally retarded child in the el mentary schools of the United States should prove both benefielel and enlightening.

\section{NARD OF CLASSIFICATION}

In the City of Louisville, there are over four hundred children both White and Negro who are members of Ungraded Classes. All of these children elthough they are referred to as "mentally-retarded" may f1t into any one of three clessifications, the academically retarded, (the child who needs special coach work), the mentelly reterded, and the emotionally unstable. If the ungraded class is to serve its purpose, there must be a clear defining of what children should be placed in wich class. As there are three distinct typos, it would be advisable to clarify thoir qualifications.

\section{DEFINITION AND CLASSIFICATION}

The mentelly handicapped may be divided into three groups, the Unadjusted or Maladjusted, the Special Mentel Disability Retarded and the Special Bducational Disabilities. These definitions and classifications 
were complied by the Whitehouse Conference on Child Bealth and Protection. (2)

To the Onadjusted or Maladjusted belong those children whose intellectual subnormelity is associated with ineffectual behavior, those who have behavior disturbances not sufficiently serious to evoke social judgent of personal-social inadequecy, but in which reterdation or intellectual subnormelity is associated with mental instability, personelity defects. psychopathic tendencies and similar deviations. These children require instruction in special classes in public schools, such as adjustment classes, particularly class or predelinquent classes where specielized Instruction belps to overcome speciel disability of behavior in spite of 10w intelligenoe level."

The Speciel Mental Disability Retardation or intellectual subnormality is associated with some pecullar mentel disability often basically physical or situational in attention, memory, perception or language, and these children require instruction in differential teaching or coaching classes designed to meet their particular needs."

"The 8pecial Educational Disabilities group includes those children vhose intellectuel handicaps are associeted with the environmental conditions at home or at school auch as illness, pupil-teacher antagonism, bad study habits, as contrasted with the constitutional handicap of the preceding group. The children are helped through individuel instruction (restoration classes) in which they regain their appropriate educational level s".

(2) Whitehouse Conference on Child Health and Protedtion. Speciel Fducation. The Hendicapped and the Gifted (Roport of the Commttioe on Special Classes.) New York, the Century Co.. 1931, pp. 335-336. 
Although there is no official classification in the United States, there is a tendency by most writers to make a three-fold classification of the mentelly handl capped that varies slightly from that of the Whitehouse Conference.

This clesalfication of Ingram seems to be the one most used.(3)

\section{Mentelly Backard:}

This groups, which comprises between 15 and 18 percent of the school population, is made up of children with intelligence quotients between 75 and 89. While these children cennot cope successfully with the average elementery school curriculum, they can gain fair control of words and numbers. In some school system these children are placed in slow-moving soctions, but in many instances no provisions for them are made. Mentelly Reterded:

These children, with intelligence quotients renging between 50 and 75. cannot meet the soctal-educetional requirements of the regular school clesses. They are often enrolled in speciel classes or in special sohools for the mentally hendicapped. These clesses have been called by various nemes, "8pecial", "Ungraded", "Binet", "Opportunity", etc. Heoble-minded:

This is the group with intelligence quotients below 50. They are incepable of gaining control over words and numbers and are most frequentiy pleced in state-supported institutions for the feebleminded. Some of these institutions provide an edueationel program, while others offer only custodial care.

(3) Ingrem, Christine P., Bducation of the Slor-Learning Child. Forld Book Compeny. Yonkers-on-the-Hudson, Now York; 1935, 5-7. 
In Louisville, children with an intelligence quotient of 50 or $2 e s s$ are excluded from public schools. The witer has found from her discussions with principals and teachers that ve, in Louisville, recognize the mentallyretarded and the mentally-backward as mentally handicepped chlldren. The emotionelly unstable child although he presents a problow, does not fit Into this category.

\section{LTMITATION OF PROBLAM}

The scope of ungraded classes with the three tjpes of children who are now their members present too varied a field to be included in one study. Each type of child presents a different need. With this concept in mind. this study is boing made with principal thoughts and reforences directed to the care of the ntally-reterded child in the elementary school.

Beceuse of compulsory school laws and the American ideal of educetion for all, these children of limited ability are coming to school. The presence of these children in school in a regular class or in special classes brings about a need of how best to help them.

The mentally-limited child usually comes from a family of low-income and he lives in crowded querters or congested areas. Most of these slowlearners come from homes those members have limited or no education. No reading matter and meagre means of spending their leisure are found in these homes. These children, if they come to school regulerly, stay the time required by law then leave school and often become dependent on society in one manner or another. They often feel that they are not qualified to be a member of a desirable group and because of their dosperate need for self-satisfaction become emotionally-unstable. This again presents another 
problem. The mentally-retarded child who experiences repeated failures In the normal classroom because of his inability to read and do normel eless work loses the feeling of self-confidence. He often develops defense mechanisms in rebellion egainst situations beyond his control. "By far the greatest single cause of pupil moledjustment is the failure to learn normelly to read. That this is true is not astonishing when the importance of reading in the usuel school program is considered. The major part of a pupil's day bejond the primary grade $1 \mathrm{~s}$ spent in reading. Obviously, the child whose skill falls below that of his follows is sonsitive to failure. He foels the 1088 of security with his peers. his teechers, and his parents. Thus the foundation is laid for serlous meladjustment, academic and emotional."(4)

About the only way to help these chlldren is through the resources of the speciel classes of the school.

School programs developed to help the individual, plus adequately oquipped buildings and trained personnel mas do much to help the mentaly retarded.

The primary concern of schools should be the training of all children to participate in a democratic society both as children and as adults, to fece the problems of today and tomorrow.

"school progrems that stimulate the child's interest, promote his intellectual growth, give to him a sense of achievement and prepare bim for userul adul thood."

The mentelly-retarded child who is unable to compete with other

(4) Bohools end Classes for Bxceptional Chilaren, The Child yith A Problem. Los Angeles school Publication No. 315, p. 7. Los Angeles, Celifornie, 1938. 
children of his own age group may jield to harmful influences. Consideration should be given to the difficulty they face in attempting to fit into school programs, to play with other children on equel terms, to prepare for self-supporting and satisfying employment."

"Provisions should be made for general and vocational education for the child of limited ablitity and should be designed to discover, and develop fully his abilities and aptitudes."(5)

The mentel ages of the children in most special classes for mentally retarded children in the elementary school range six to twelve years. Their Intelligence Quotients are approximately in the range from fifty to seventy-five.

As these mentally-rotarded children cannot meot the socialeducational requirements of the regular school class, they must be provided for in such a way as to make them happy, healthy, competent and selfsufficient adults.

Meny mentally-retarded children become maladjusted, truant, and frustrated delinquents because thes have become recipients of undesirable and unnecessary methods. Because of his inability and refusel to do he has received diseiplinary measures frequently and counter rejection is practiced. He rejects the situation provided by adults, the adults reject the child who fails to succeed according to the adult plan.

The fallure of the teachers, principals and supervisors who fail to recognize the individuality of growth and plan accordingly lead to the stage that make the problew child. Consequently, these children should be placed where understending their needs in relation to their abilities

(5) U. S. Department of Labor, Children's Bureau: 1943. Controlling Juvenilo Delinquency, p. 23. Nashington, Government Printing Office. 
to grow and learn is stressed.

Usually, the child who is mentally retarded has scoe asset, perhaps a special ability in art, handwork, music or oven a definite personality trait wich a skilled interested teacher can discover and develop to the híghest degree.

DNFINITE LOCAL NBRD FOR THE STUDY

It will be necessery to understend the prevailing trends and issues in other cities and to comprehend their successes and failures before a critical analysis can be made of the care of mentally-retarded children and their allocation in special classes in the Loulsvillo elementary schools.

There appears to be a need for improvement in the clarification of what constitutes the basic foundation of the ungraded olass. Too often the trend locally has been to make the ungraded elass the recipient of the montally-retarded child and the enotionelly unstable child from eight to sixteon years of age.

A serlous problem then develops in attempting to provide edequate adjustment and help to the mentelly-retarded child.

-If ungraded classes are to function as special classes should function, it is essential that their real purpose be thoroughly understood by both principals and teachers and that classes be organtzed to fit the needs of those for whom they have been establishes."

While the classes are essentielly for mentally-hendicapped chlldren, it is evident that they are also used as stop-gaps for some of the misfits and discipline problems in the regular classes until ouch a time as these boys and girls can be excused from school attendence." (6)

(6) Loui sville Public School Surver - R Report on the Public Schools of Louisvilie, $\mathrm{Kr}$. p. 288. Surver made by Mr. George A. Norks. Published by City of Louisville. Ky. 1943. 
With interest aroused by these comments of the Works Survey and with knowledge of the prevailing trends and issues involved in Loulsville, there is a sincere hope that the information to be gained as the result of this survey on trends and issues confronting special class directors in the United states may help to Increase the efficiency of guiding the destinies of mentaly-retarded children in the Louigville public schools.

The elementary schools of Louisville now have a supervisor of Special Ifducation who is vitaly interested in clarifying some of the problem involving the ungraded classes. Scme of these factors, membership classification, cless limit, curriculum or course of study are now being discussod by the supervisor and her special class teachors. This fall they plan to form a desirable and enriching course of study. It is hoped that the results from this survey mar prove to be beneficiel to the supervisor and the teachers in their planning.

$$
\text { METHOD OF PROCEDURE }
$$

Before an attempt can be made to ascertain the prevailing trends in other cities in the United States, it is necessary to find out the prevaling trends in Louisville and the issues involved in the administration of these classes. Through a series of interviews with various princ1pels of the elementary schools, a consensus of opintion will be formed and stated.

After the trends in Louisville are escertained, a questionnaire wll be made besed on the findings, and will be sent to the Directors of Bureaus of Research on Special Classes in key clties in the Onfted States. The questionnaire will be made to include the most signiflcant points about which knorledge is vitally needod. After a statement is mado to clarify the witer's meaning of mentelly-retarded, the following factors will be sought. 
1. Attendence or membership in Ongraded or Speciel Class.

2. Mothods of selection.

3. Knowledge of child before acmittance to class.

4. Housing of class or classes.

5. Qualification or requirements of teachers.

6. Supervision.

7. Curriculum.

8. Miscellaneous factors.

A copy of the questionnaire will be found in the Appendix.

Irom the returned questionnalres, a compilation of the factors Involved will be mede. These factors will be anelyzed and their good and bad points are to be considered without restriction in Chapter IV.

Chepter III will be devoted to a discussion of the prevailing trends and the issues involved in the administration and enroliment of the ungraded classes in the elementary schools of Loulsville. This information vill be gained from interviews with principals, and teachers of elementary schools, members of the Department of Curriculum and Research and the writer's experience as a teacher in an ungraded class. 


\section{GHAPTISR II}

A SURVEY OF RRLATRD INFORMATION 
CHAPTER II

PART I

IDENTIFICATION OF THE MENTALUY-RETARDED 


\section{DNTRODUCTION}

In Chepter I a meagre attempt was made to identify the MentaliyRotarded child. As it was stated in the preceding chapter, the writer is not concerned with the curriculum for the mentally-retarded child as this would cover too vast a field in connection with the problems of administration, therefore, the following questions seem to be foremost in this study. Why are people concerned with the mentally-retarded? How are the mentally handicapped divided? When did we become interested in then? How often do they appear in our school population? How can ve 1dentify them? What are their possibilities for development? What are some of the problems of administration of the mentally-retarded?

This chapter will intend to form a framevork of the realism of a person known as mentally-retarded, what is knom of him, how he fits into the program of equal educational opportunities and some suggestions of the care that may be given him.

\section{WHO ARE THE MENTALLY-RETARDED?}

Quito ofton such expressions as "backward," "mentally-rotarded." "mentelly beckward," "dull," "slow-learner," "bdderline," "feeble-minded." and others are used interchangeably without the exact meaning. One person thinks of one meaning, while enother thinks of something else. This confusion has gone on for conturies. As early as the seventeenth century. at tompts were made to define low mentel ebility. The Church, the law and medicine each tried without success. Later, social-economic and pedagogical and psychological definitions appeared. Before the use of intelligence tests, the definitions were usually made in terms of sociel adjustment. Wuch value may be attached to this plan as it involved observations of the practicel adaptability of children and adults to 
social living. Intelligence tests were developed and the concepts of mental age and intelligenoe quotient helpod to classify the mentallyhandicapped.

These handicapped people are not distinct from other members of the human race, they simply have a reduced capacity to think through and to golve many of the ordinary problems of living and often lack the judgement and competence to handle themselves in the sociel world.

It is not easy to generelize about the characteristics of the mentelly-retarded as compared with those of normal mentality, but some are noteworthy. They show in addition to the gross retardation in terms of mental age the following factors according to Baker. (I)

Qualitative psychological backward ways.

1. They show a tendency to stereotyped answers by repeating the seme response to different questions.

2. They lack powers of self-oriticism.

3. They possess IImited powers of essociation.

4. They are unable to keep unusual instructions in mind, but return to traditional methods.

5. They fall to detect errors and absurdities in statements and in commonplace situations.

6. They tend to have concrete abilities rather than abstract.

7. They have Iimited powers of reasoning, visualization and similar mental traits."

As a group, they are likely to have more physical deviations then normel children. Often crowded and poorly formed teeth, ears of meny odd shapes, umsual size of the head, posture or other unusual conditions mark the mentelly-reterded. These beses elone would prove disestrous as a means of diagnosing mentally-retarded children. Although many children

(1) Baker, Harry J. Introduction to Exceptional Children. The Macmill an Company. New York, 1945. p. 258. 
do not possess these severe deviations they have defects that may be found In normal children, such as enlarged tonsils, adenoids and bad teeth. These physical defects added to their educational retardation prove to be a handicap.

During the past quarter of a centur, much has been done to classify the mentally handicapped by the use of psychologicel measurements and definitions.

\section{CASSIFICATION AND DEFINITIONS}

In 1913, England passed a Mental Deficiency Act that divided the mentally-handicapped Into throe groups: the feeble-minded, imbeciles, and ldits. The groups were thus defined:

The feeble-minded are persons in whose cese there exists from birth or from an early age mental defectivenoss not counting to imbecility. jet so pronounced that they require oare, supervision, and control for their own protection or for the protection of others; or, in the case of children, that they by reason of such defectiveness appear to be permanently incapable of receiving proper instruction in ordinary schools."

Imbeciles are persons in whose case there exists from birth or from an early age mental defoctiveness not amounting to idiocy. jet so pronounced that they are incapablo of managing themselves or their affairs, or, in the case of children, of being taught to do so."

"Idiots are persons so deeply defoctive in mind from birth or from an early age as to be unable to guard themselves against common physical danger." (2)

(21) Frampton, Merle $\mathrm{D}$. and Rowell, Hugh G., Bducation of the Handicapped. World Book Company. Yonkers-on-the-Hudson, New York; 1940. p. 330 . 
In 1931 a Jolnt Committee on Mental Deficiency in Ingland adopted the following classification which was mede officiel in England.

\section{"Mental Defective:}

Those children whose mental age is bel ow helf the chronologicel age; that is, those of ton whose mental age is below five. These we propose to call mentelly defective children. (I.Q. below 50)."

\section{"yore Reterded:}

Those children whose mental age is above half and below seven-tenths of the chronological age; that is, In the case of children of the chronologlcel age of ten, those whose mentel age lies between five and seven. These we propose to cell 'more retarded' children. (Corresponding broadly to those hitherto classified as 'educable mentally defective' children). (I. Q. 50-70)."

\section{Less Retarded:}

Those children whose mentel age lles between seven-tenths and eighttenths of their chronological age; that is. in the case of children of the chronological age of ten, those whose mental age lies between seven and eight. These propose to call 'less retarded' children. (I. Q. $70-80) \cdot n(3)$

As It was stated in Chapter I, there is no official classification in the United States. The one adopted by most educators to be the most practical is the three-fold classification of Ingram.(4)

(3) Ibid, pp. 330-331.

(4) Ingram, Christine P., pducation of the slow-Learning Child. World Book Company, Yonkers-on-the-Hudson. Now York. 1935. P. 5-7. 


\section{The Mentelly Backward \\ 2. The Mentally Retarded \\ 3. Fooblo-minded.}

As these vere defined in detall in Chapter I, 1t might be significant to say: that group I includes those whose intelligence quotients are between 75 and 89; that group II includes those whose intelligence quotients range between 50 and 75 ; that group III includes those whose intelligence quotients range below 50.

It has often been stated that boys and girls who lack the capacity to grasp or profit by the works of regular grades are subnormal. The critorion of school progress or of educebility alone is highly unsatisfactory as a means of classification.

Wallin contends that $(5)$ Mducability depends on many of the factors that imate strength of mind, inherent capacity, alertness or intelifgence; for exemple, such factors as interest, enthusiasm, ambition, effort, application, early training, age on entering the school, regularity of attendence, the cultural advantages afforded by the habitat, emotionel drive and stability, health, and specific mental, physical or educational defects."

Although an actual trial can be made to determine the degree of educability of a mentellj-retarded child, this would prove to be of a great disadvantage as the child would receive very little training which would prove beneficial to him. This was rocognized in 1929 when the Legi slature of the state of New York amended its special Eucation law. Previous to 1929. a child with an Intelligence Quotient of 70 could not enter a speciel class unless ho wes ten years of age, thereby losing the

(5) Mallin, John I.I., Bdueation of the Hendicepped Children, Riverside Test books in Education. Houghtion-difflin Company, 1924 p. 350. 
first four years of his school training. The new amendment oliminated the required three or more jears of retardation, and permitted children to enter as soon as they vere tested. There is no question but that some relationship between ixtelligence and school achlevement does exist. Although A. F. Trodgold $(6)$ statos:

"... low capacity for school learning doos not mean lack of general intelligence and that mere scholestic inability cannot be regarded as a criterion of mental deficiency "

Paychological data can be of much help in determining the criterion of school progress.

Wallin(7) sars: Mental inferiority can be diagnosed only by means of a psychological examination. The psychological exentnation gives importent clues regerding the degree of educability of the child, the kind of training neoded, the occupationel possibilities, and the required social control or dispostion."

In 1904, when Binet developed a scale for the detection of feebleminded ohlidren in the school systems, there began a scientific menner of determining individual differences. From these tests numerous facts have been revealed, one of which is the frequency with which various degreos of intelligence occurs anong school children. Humen nature varies from the mental deficlent below an I. $Q$. of 50 to those who are mentally supernormal vith an I. Q. above 125. There is a general agreenent that the child whose I. Q. Is 50 or less be excluded from the regularschool and be placed in an institution. Just as there ere exceptions to all rules, so

\footnotetext{
(6) Tredgold, A.F. Uentel Deficiencr. Wm. Nood and Company, New York. 1928. p. 3 .

(7) Wallin, Op. ait. p. 347 .
} 
do we find scattered throughout the Unitod States some children whose I. Q. are belor 50 attending regular classes. These cases are either in rural areas or in locelities were no special classes exist.

\section{FREQUENCY OF APPEARANCE}

In terms of frequency mentally-retarded" children constitute at least two to five percent of the juvenile population according to facts geined by Martens.(8)

In the Distribution of Intelligence Cuy. L. Hilleboe (9) states that in 1926 , (1) out of 34,080 pupils in grades $1,3,4,6,8$, and 9 in Detrolt, 10.3 pupils were of borderline deficlency and 13.2 were below average.
(2) In grades $6 \mathrm{~A}$ and $8 \mathrm{~A}$ 3,164 pupils Rochester, New York
4.9\% borderline $11.4 \%$ below average
(3) In grades 4 to 8 Buffelo, New Yorl
$8.8 \%$ borderline
$7.9 \%$ below average
(4) In grades $6 \mathrm{~A}$ and $8 \mathrm{~A}$ 3,164 pupils
8.1\% borderiline Philadelphia, Pennsylvania.
$7.9 \%$ below averase
(5) In grades 3 to 8 16,138 pupils
$16 \%$ below average
Belltimore, Maryland
(6) In grades 4 to 8 1,325 pupils New York C1ty
5.7\% borderlino
$18.0 \%$ belon average

Thus it can bo seen that we have many children in our school systems that are below normel in intelligence. According to this report, we can see

(8) Martens, D.H., A. Guide to Curriculum Adjustment for Mentelly Retarded Children, Govermment Document No. 11. 1936 - p. 1. 0. S. Office of Bducation, Nashington, D. C.

(9) Hilleboe, Gus L., Finding and Teaching Atrpicel Children, p. 28. Bureau of Publication Teachers College, Columbia University, Nev York, 1930. 
that of the pupils tested. Detroit had $23.5 \%$ below normel

$\begin{array}{ll}\text { Rochoster } & 16.3 \% \\ \text { Buffelo } & 16.7 \% \\ \text { Philedelphia } & 16.0 \% \\ \text { Baltimore } & 16.0 \% \\ \text { New York City } & 23.7 \%\end{array}$

The children in Baltimore measured $22 \%$ below an I. Q. of 7 .

According to Baker:(10) An estimated total of one-half a million for the entire country could be classed as mentelly-retarded children. In 1930 there were 80,000 enrolled in special classes but by 1935-1936 the number had inereased to nearly 100,000. The most reoent enrollment figures were slightly lower than this high peak, so that less than onefifth heve special class provision. Any city of from Iive to ten thousand general population with one thousand school children should bave onough for a cless of from fifteen to twenty pupils."

Naturaly, the ectual determination is exceedingly difficult because of Ineccurate measuring instruments, lack of standardization of definition and regional differences. We find that about twenty-ilve percent of elementary school children show an incapacity for academic achievement depending upon their degree of intelligence.

MONS OF DISCOVERINO THE MENTALLY-RETARDED

\section{Derly History}

Leny jears ago the idea that subnormality as a condition that had special supernatural significance prevalled overywere. At times they were supposed to have the power of the gods or belleved possessed of evil spirits. Men like Rousseau and Locke directed their ettention on basing

(10) Baker, Harry J. Introduction to Exceptionel Ghildren. New York: Macmillan Co. 1945. pp. 261-262. 
education on the child's native instincts and capacities. In 1837 a school for the mentally retarded was established in Paris, by a French surgeon. Many well-known Imerican educators became interested in the mentally-retarded, Including Horace Mann, and Dr. Semuel G. Howe. The first classes were in state institutions. It was not unt1 1897 that the public school systems establishod special classes. The first one in the United States was at Springfield, Massachusetts.

That the mentally handicapped child needed instruction adapted to his individual needs, Interests and abllity was rocognized by the Chicago Board of Education as oarly as 1891, according to zahrobskg(11)

While Chicago cannot claim the honor of being the flrst city to inaugurate day classes for the instruction of mentelly subnormel children, It cen claim the distinotion of being the first city in the world to establish a child study department within the public school system where the child's particular difficulty could bo diagnosed and a plan of treatment suggested.

The experimental classes which were first tried in 1891 soon turnod out to be the place where any child who, for one reason or another. failed to succeed in the regular classroom was transferred. Il though these early classes did not prove to be the solution for meeting the needs of the mentally deficient, they served the purpose of demonstrating the need of diegnostic services. With the establishment of a child study department in 1899, It was possible to select on a more seientific basis those children whose difficulties were due to intellectuel inferiority.

(11) Zahrobskg, Mary, The Illinols Program for Educating Handicappod Children in the Public Schools" The Soc1al Service Revien. Vol. 20. June, 1946. p. 193. 
The first special class limited solely to mentelly handicapped children was established in Chicago in 1900."

Since then the growth of special clesses in the United States has been slow but steady. The principal growth has been in the eastern states. hocording to zahrobskg(12) "In the year 1939-1940 out of forty-two states. Illinols ranked ninth in the states conducting special classes for mentally deficient children, being surpessed, in order of numerical Importance by New Yorkk Pennsylvania, Massachusetts, Maryland, Cellfornia, Michigan, Ohio, and New Jersoy *

\section{MEANS OF DISCOVRRING THE MENTALLY-RBTARDED}

\section{Lethod}

Some states have laws concerning the establishment of special classes for mentally-retarded, others leave thematter up to local athorities. Greater strides have been made in the eastern states because of legislative action. New York. New Jersey, and Massachusetts have made It obligatory for boards of education to ascertain the number of pupils in each school district who are three or more years mentaly-retarded, and to establish special classes for their instruction when ten or more children have been found who need speciel instruction.

The State Commissioner of Bducation in Now Jersey is provided by Iaw to prescribe such methods as to him mas seem best for use in ascertaining what chlldren are three or more jears below normel.

A definite procedure is used by local school administrators in New York. The Research Division of New York State Department of Education outlines a plan to secure the child who is retarded in mental development. This plan as outlined in the Prampton and Rowall 1s:(13)

(12) Ibid. p. 193

(13) Irampton, Merle I., and Rowell, Hugh G., Education of the Handicapped. World Book Co. Yonkers-on-the-Hudson, New York; 1940. pp. 332-333. 
1. Examine age-grade tables annualiy to discover those pupils in grades 1 to 5 who are two or more years of over-age.

2. Secure from classroom teachers the nemes of those pupils who they believe would profit from special class instruction.

3. Secure and check nemes thus obtained against acedemic and health records and social histories to ascertain obvious causes of retardation.

4. Check records of intelligence tests, and if none are available, administer a group test of intelligence.

5. Have a qualified psychologist study all children whose retardation is not obviously due to some cause other than mental handicap.

The state Board of Iducation in Comecticut hes a ruling that states that a child with an I. Q. ranging fram 45 to 75 and a mental age not less then five jears and a chronological age of not more than sixteen Jears may be placed in a special class or school.

Most of the mentelly-retarded children are not fortunate enough to have been born in these eastern states, therefore, unless the local school authorities are able to discover them and care for them with special education, these children go neglected.

Those children who find it difficult to keep up with the ordinary pace of learning, who cannot learn rapidly and are forced to endure unfavorablo comparison with those who gain so much from a normal school situation are exceedingly fortunate if thej live in a commanity whose school system has a clinical staff (psychiatrist, psychologist, and social worker) at its disposel. They with the regular personnel can anelyze children's behavior difficulties and make recommendations and the necessary plans for roadjustmont.

Unfortunately, fow schools have this plan as many systems do not even employ psychologists. Sometimes children are teken to county or 
hospitel clinics. In some states traveling clinics supervised by the state board of education go to anj school district that expresses a need for the service.

In many instances the teachers of the special classes are required to take courses in psychometrics and they are the ones who determine whother or not the child should be placed in the speoiel cless.

There are many children who are never diegnosed and never receive the edvantages of special education. Some of these have been subjected to haphezard and inadequate methods that have been better left undone.

Frequently, the discovery of the children who are in need of speciel Cless work is accomplished through teacher-judgment, studies of grade retardation, achlevement tests, group tests of intelligence or a combination of these agencles.

Teacher judgment al one is not always satisfactory because there sometimes arlse the tendency to include disciplinary problems and many teachers do not possess the knowledge to make a definite diagnosis. The recomendation of the teacher is very good but should not be the primery basis for selection. It depends upon her knowledge to judge the factors Involved. An experiment was conducted by the Canadian Council on Child Velfare(14) In wilch instructions were given to teachers in the proper mothod of selecting children without giving standardized tests, and then compared the appraisments assigned four-hundred children with those found by the standard Binet test. The average difference wes less than five percent.

In many small comonities where teachers administer tests or make

(14) Cenadian Council on Child Wolfare. Special Training for School Age Children in Meed of Speciel Care. Ottawa. Canada. 1927. p. 10. 
rocommendations without the advantage of having had training or clinical experience in deeling with many types of atypicel children, the results would not be the same.

Farly diagnosis and assignment to a spocial class is of a great advantage.

Irvin and Varks(15) state: "Because of the fact that childhood is a plastic period when delinquency is preventable, when proper specific habits may be formed, when desirable mentel attitudes may be cultivated. when normal social reletionships may be begun, when the individual's potentielities for brain development are at their peak, and when good habits can, by the right kind of training be made to precede rather than follow bad habits, early diagnosis of mental subnormality and assignment to a special cless is essential to the ultimate success of that type of education."

Some psychologists believe that if the mentally-retarded child is given the right kind of speciel education early enough, they can adjust themselves exceedingly well. If this be accepted from a social and economic point of view, it would seem to follow that the child should be tested and diagnosed and assigned to spocial class work while he is in his first or second year of school.

In diagnosing menj factors enter besides montal tests and teacher's judgments, al though these two are quite important. The observer $\nabla$ ill realize that financial resources of a community, the size and training of the personnel all enter into the successof the diagnosis.

(15) Irwin, rlizabeth A. and Marks, Louis A. Pitting the School to the Child: in sxperiment in Public Dducetion. Tho Mecmilian Company. 1924, p. 158 . 
Hilloboe(16) presents a list of nine essential facts which in the opinion of authorities are considered essential data for diagnosis.

1. Psychological exemination

Intelligence tests

Chronological and mental age

Sensory examination

Personality conflicts

Behavior

Noral Reactions

Obsessions or fears

Special disabilities

2. Lodical examination and record

Physical age

Physical development

Physical history

3. School Record or History

Teacher rating

Rank in class

Practical knowledge

4. Heredity and family history

Economic condition

Home conditions

special disciplino

5. Enviromentel conditions

Nelghborhood conditions

Associates

Amusements

Bad mental and educational hygiene

6. Social characteristics and history

Charecter defects or traits.

7. Personal history from infancy

Personal habits

Sex habits

(16) Hilloboe, Guy L., Finding and Teaching Atrpicel Children, 1930. p. 60. Bureau of Publication Toachers College, Columbia University, Ner York. 


\section{Pajchiatric examination \\ Heurological examination \\ Emotional problems \\ Reaction to ordinary situations \\ Delinquent tendencies \\ Psychopathic tondencies \\ Temper ament}

\section{Vocational record."}

The most important as indicated by the authorities ves individuel intelligence tests, school records and history, medical exanination and record, and the family history and beredity.

It is highly essential to obtain a family history. Wallin(17) states that mentel subnormality is from 75 to 90 percent hereditary and that abnormal mental states are what they are because of their antecedents and cannot be adequately understood or interpreted apart from their evolution or development.

After the diamosis hes been made, one of themost important duties of the diagnogticien is the recommendation of remedial measures, and the report of all the factors in the diagnogis should be given to the teacher who will have the child under her jurisdietion.

In the recomendation or assignment, many factors require attention. In most states children wose Intelligence Quotient is 50 or less are excluded fran public sohools. As stated previously, there are sane exceptions and we find some children of less then $50 \mathrm{I}$. Q. attending the public schools in normel classrooms. The admission of this type of child to normal classrooms should be barred because of the stigme it would give to the other pupils, and the reputation it might give the school.

(17) Wallin, John B., Glinicel and Hormal Psrchologr. Houghton Mifflin Co., New York - 1927, 649 pp. 
The special class should not be a dumpling ground for all the excoptionel pupils in the school. Age and mentality should be the two main oriteria for assigmment to the special class. The Intelligence Quotient should range from 50 to 70 in the special olsss. Coaching teachers should be assigned those children who are of normal intelligence but backward in school progress. The behavior problem or the temperamentally atypical child should not be permitted to become a part of this speciel class. He often has bad effects upon the suggestible minds of the mentally-retarded and frustrates the efforts of the teacher. 
GHAPTER II

PART II

THE PROBLEMS OF ADMTNISTRATION 
Hous nor

Wost school administrators are faced with the problem of how to care for classes for mentelly-reterded chlldren.

How many classes should they establish; where should they establish these classes, and how should these clesses be equipped? are questions uppermost in the thoughts of administrators of special classes.

The pressure of the problem and the limitation of the locel situation will determine the most effoctive administrative technique in each community.

Although meny plans have been tried in various communities, the tendency in this country seems to be to establish one or two special classes in a regular el ementary school.

Frampton(18) gives five reasons why this is prevelent: 1. Locessibility:

If these classes are scattered throughout the city. no child w11l have to travel an unreasonable distance to sobool and the oity will not have the added expense of providing transportation.

\section{Less parentel opposition:}

Parents are less likely to be disturbed over the transfer of a child to another class in the seme bullding than over a transfor to another school. The neighbors are less ilkely to notice such a transfor and coment about 1t.

(18) Frampton, Merle B., and Rowell. Hugh G., Bducation of the Handicapped. Morld Book Compeny. Yonkers-on-the-Hudson, New York; 1940. p. 334. 
3. Loss st1gma attached to the single class:

The advocates of this type of orgenization believe

that less stigme is associated with such a class than with

- special class school for the mentally handicapped. There

is no evidence to show that this need be true.

4. Groater opportunity to associate with normals:

The child is in a school largely populated by normel children,

, he will have an opportunity to associate with them and to com-

pote with them in activitios in which he has a chence to succeod.

5. Greater ease of transfor to a normal cless'

It is easier in such a situation to allo the dull child to be transferred to a normal class if his progress warrants such a transfer. He may spend part of his time with a normal group and part of his time with the slower group." Meny educators disagree with this opinion and advocate a spocial center or special school. As outlined by Frampton(29), these are considered advantages of the speciel center or school plans

i. Better classificetion of pupils:

If there are several classes it is possible to place in one group those of similar chronological, educational, mental, and sociel ages whereas if there is only one class there may be so wide a range of age and interests as to meke the group very difficult to teach.

2. Posgibility of promotion:

In such a setup the child mas be promoted from one class

(19) Ibid. pp. 334-335 
to another and thus have a more definite feeling of progress

then is possible whon he must remein in the same clessroom

for several years.

3. Contact Ith more teacherg:

Instead of having one teacher for several years the

child has the experience of adjusting himself to several

teachers during his school career. It is also possible that

some of thework may be departmentalized and the child may

work with more than one teacher in a single year.

4. Possiblilty of a more yaried program:

With several teachers, each with special talents and

training, it is possible to offer a greater variety of experiences

than can be offered when only one special class teacher is

avallable.

5. Pconomy:

Shop equipent is expensive, and if the classes are brought Into one center there is economy in the purchase and use of equipment.

6. Mental hrgiene:

The handicapped are competing with their peers. There is greater possibility of success and reeter possibility of good adjustment ."

As with every question, there are always two sides. In 1945 stevens(20) as a result of his experlence as a director of special education, dis-

(20) Stevens, G. D. "An Evaluation of some Methods of Organization of Gasses for the Mentelly-Reterded Adolescent." Bducetional Administration and Supervision. Volume 31. April, 1945. 
cussions with field workers, and a reviev of limited Iiterature concorning the single elementary school special class stated that the onrollment usually consisted of from fifteen to twenty children of from six to sixteen or eighteen jears. The teacher may or may not be trained and the equipment and curriculum is usually modified to child. He stated that there were four advantages:

"1. Good for small systoms ith for mentally-retarded children.

2. Better adepted from viewpoint of personnel, equipment and curriculum.

3. More individual attention.

4. Fower personelity maledjustments."

Whle on the otherhand he 11sted eight disadvantages:

1. Difficult to adjust curriculum to chronological age, mentsl age and social maturity of cless.

2. Impossible to provide fully for individuel differences.

3. Impossible for elementery school to provide mature social interest.

4. Hementary curriculum unable to satisfy physical and personality need.

5. Hquipent not suitable for older child, desks, seats and so forth.

6. Play and sex interests vary.

7. Sometimes the elementary teachers are not prepared to handle problems of adolescents because of primary training.

8. Older children become stigmatized."

As stated previously, many educators do not like the idee of one or two classes but prefer a special school center. stovens(2l) speaks of a

(21) Ibid 
spocial class elementary school center as one in which severel spocial classes are brought under one administrative unit elther as a part of a regular elenentary school or in a separate bullding. The curriculum. instructionel materials, equipment and all facilitios are for the elementary school age child and especially adapted for the needs of the mentally handicapped of the pre-academic to the adolescent pre-vocational or oecupational age group. The teachers are usually trained and have a trained supervisor. He lists seven advantages of this plan.

1. Greater degree of homogeneity in grouping.

2. Better equipment, railo, moving pictures, well-quipped shop. Ilbrary.

3. Child comes in contact with more teachers.

4. More social growth by participating with children of similar mentel. social and educational lovals.

5. Regular elementary school equipment available to cless.

6. Broader curricular experiences because of greater number of teachers.

7. Provocational and vocational training because of shop courses.

To this plan, is 11stod four disadvantages:

"I. The cost prevents it in smell school systems.

2. Elementary school teachers poorly equipped to handle adolo scent.

3. Curriculum attuned to elementary school child unable to meet physical, sociel and personelity need of older children.

4. It tends to stigmatize the child (dumb school) often prevents child from getting jobs."

It is an accepted principlo that all children should be provided equel educational opportunities and the mentally handicapped must be pro- 
vidod for In such a manner as to make him a heal thy, happy, compotent and self-sufficient adult.

In American City, the city so designated by the Educational Policies Commission(22) in its plan for school services for jouth as they would 11ke to see them in the post-war years, the following provislons were made for the mentelly-hendic apped.

The school foll ow here the policy of minimizing segregation. These Jouth, it is held, have the seme needs as others. They too will work, earn money, spend their earnings, be members of families, be in good or 11 health, vote in elections, be members of organizations, and use their leisure tim wisely or otherwise. They are more likely to learn to do these things well, it is believed, if they work in association with other students."

Whether tho children are in regular classes, single elementary classes or in a special school center evolves itself around a number of circumstances. The number of mentally-retarded pupils, the size of the eity school system, personnel, equipment, finences and other factors enter into the prevelent type. It is to be understood that in large cities similar to Los angeles. New York and Chicago there would be a more eleborate plan of spocial education then cities in comparable size of Louisvilie could be expected to have. For that reason the questionnaire in this study shell include those cities comparable to Louisville. It is to be considered that in rural and small town schools where the number of mentally-retarded children is considerably 1083 that it would be too lavish

(22) Iducationel Policies Comission. Iducation for All Imericen Youth. National Educational Association of the United states and the American Association of School Adminlstrators. Neshington, 1944. p. 334 . 
an expenditure to establish special classes. These children arekept in regular classes in the school.

Zahrobskg(23) speaks very highly of Chlcago's care of her mentallyhandicapped children but states: "Nlthough public schools outside the eity of Chicago in some instances offer special educational services to mentally handicapped children, these are comparatively few in number and are to be found only in thelerger cities and towns. In as recent a school year as 1939-1940, a perlod from which comparable statistics from other states are available, there were but 4.252 mentally deficient children wo were attending special classes in the public schools of twelve Illinols clties. Of this number, 3,716 or 87 percent were enrolled In Chicago Public Schools."

The teachers in these schools must be elert to the needs of these special pupils and must adjust the curriculum and their teaching methods to meet the noeds of these exceptionel children.

If these mentally-retarded children are to be assigned to classes that will best fit them to use their capacities to the fullest extent, certain criteria must bo emphesized by administrators. Good physical enviroment, trained teachers whose personelity fit them to understand and help these children, a curriculum developed to meet the neods and capacities of the individual, remedial treatment which will help to reduce or eliminate mentel or temperamental handicaps, guidance and a follow-up plan after the pupil leaves school are all important factors to be considered in the plan of administration of special education.

(23) Iahrobsky, Mary. "Educating Handicapped Children in IIlino1s Public Schools." The Sociel Service Revier. Vol. 20, June, 1946. p. 193. 
THE PHYSICAL ENIRONLEN

The physical envirorment should be comparable to that held desirable for normel children. A mentallj-retarded child does not learn better in a dingy. 11l-11ghted uncomfortable room. Too often that is the type of room of fered to the mentally-handicapped child. Administrators are beginning to realize the need of providing the proper equipment and suitable quarters for these children. Onless the child works under good physicel conditions, he cannot be expected to maintain either physical or mental health.

\section{IMPORTANGE OF TRAINED PARSONALL}

As it was proviously stated in this chapter, the teachers of some special alesses are required to take courses in psychonetrics to determino the advisability of placing children in speciel alasses. Although this prectice is not prevelent, there is a definite need for vell-trained teachers for speciel classes. It is important that these teachers be especially equipped with the desired understending personality and urge to help these mentelly-rotarded children. Because of their mental handicap, they noed a teacher who understands their need of adjustment and is sufficiently alort to develop a constructive plan. Teachers of handicapped children should have some general knowledge, first, of the teaching methods usod wth normal children, and, second, of the noeds and problems of the mentally-handicapped. An avareness or general orientation course in the education and psychology of all exceptionel children is often a requiremant for every specialized curriculum in special education. Knowledge of each handicap and methods used in teaching various groups of exceptional children proves beneficial. Departments of psychology, sociology, speech, 
biology, physiology. Industrial arts and physical oducation are all used in the preparation of teachers of handicapped children. NARD OF AN ADJUSTED CURRICULUM

The curriculum is graduelly undergoing a change. At first the minimum essentiels of the traditionel elementary school curriculum plus some handwork constituted the curriculum for the mentelly-retarded child. In some areas the main Idea was just to "keop them happy".

The education aims for mentelly-retarded children as related by Martens(24) are no different then that of any group of children.

Mhis aim is to teach the individuel how to live better; to tesch him to use all of his capacities; to teach him to become a useful membar of a social group."

Ihophasis should be placed on certain factors if these fundamental aims of education for the mentally-retarded child are to be reallzed. Martens(25) states them thus:

1. Mducation in keoping with the capacities, limitations and interests of each child.

2. Bducation for some participation in the world's work.

3. Education for wholesome social experiences.

4. Education in keeping with the interests of all children."

Teachers really should be the ones to supply the curriculum and should also help to formulate a phllosophy and assist in working out the objectives of a definite progrem of adjustive curriculum. Everyone

(24) Martens, B. H. A Guide to Gurriculum Adjustment for Mentellr Reterded Children. p. 15. V. S. Office of Education, Neshington, D. C.. 1936. No. 11 .

(25) Ibid - p. 19 . 
does not have the ability to produce ourriculum materiels, but if each member of the special education staff is stimumated to express his beliefs and attitudes a desirable curriculum may be moulded. Techniques cannot be accepted rashly, they must be tried out, evaluated and quite often modified. Just as Iife is constantly changing, there must be before the administration and supervisory staff the realization that the human and social needs of retarded children chenge. The responsibility of caring for these changes must be met by the entire staff. Then, and only then. can the true curriculum be developed.

We so often wonder what the mentally-retarded can learn that will be useful to him as an adult. A praotioal skill in theuse of the tool subjects, habits of honesty and industry, a knomledge of the importance of physical efflciency, some basis of earning a living and an awareness of a worthy use of leisure time should be the outstanding objectives to be developed in the mentally-retarded child.

Meny worthwile traits like neatness, punctuality, alertness, trustworthiness and others need to be omphesized.

Many interesting experioments in the adjustmont of the curriculum of the mentally-retarded are being carrled out in the United States. One of the most interesting of these is the one conducted at the spejer school (Public school 500) in Now York City as related by Drs. Arthur Gates and Mirien Pritchard.(26)

As this was a curriculum exporiment at Spejer school, and this report is on administration, the witer shell not attempt to discuss the

(26) Gates, Mrthur and Pritchard, Mariam. Teaching Reading to Slor Leerning Pupils. Bureau of Publications, Teachers College, Columbie University. New York. 1942. pp. 65. 
experiment but simply report the studies. The first was based on records of six classes of slow-learning pupils obtained botween February 1936 and June 1939. The second was based on the regults obtained from reading tests, questionnaires and interviors of one class in the spejer school. and control group selected from enother public school in the same neighborhood. This study occurred in the fall of 1940. One of the mejor purposes of the experiment was to determin the value of each of several medie of learning for children of glow-normel group. It was really the major importance of reading versus those who felt that slow children find roading difficult and unappealing and that other modes of learning through direct observation, such audio-visual aids as motion pictures. sound-motion pictures, construction enterprises, comersation and others would prove to be more interesting and more fruitful.

How the studies were carried on over a period of time 1 s discussed In detail and the results of the studies summarized.

The needs of the child and the development of his potentialities should be uppermost in the formation of a curriculum. The teacher is aware of her pupils needs and she should see that the curriculum meets his need.

Patey(27) feels that the focal point of the school's work is the classroom with the teacher serving as the general practitioner talding care of the pupil's needs.

'If I. Q's were the basis for classification, it would be possible to develop curricula that would be continuous over a period of years.

(27) Patey, Henry C. The Teecher as a General Practitioner in Mentel Hygiene." Mentel Hyglene. Vol. 24, Oct., 1940. pp. 612-613. 
There are enough of these mentally-retarded children to justify the time and effort spent in developing courses applicable to their special needs.

The developing of special courses adapted to the need of the variety of abilities represented in the public schools depends upon an edequate progrem of educational guidance, It is easy enough to generalize about these problems, but a person who is oriented in mental hygiene will want each program generalized from the needs discovered in their individual children, that is, from the carefully considered recommendation for individuals.

An able teecher can develop a course that will serve the particular needs of his or her pupils, and still meet the general requirements of the curriculum, if given sufficlent leevey for a sufficient period of time. The problem way be solved by using guidance with curricular possibilities."

VALUE OF GUIDANCE TO THE MENT ALEY Y RETARDAD

One of the greatest misfortunes that occurs to the mentally-retarded child is that efter he has been placed in the special class, he is quite often forgotten as an individual by those who placed him there. Irwin and Marks (28) consider that the initial survey and placoment of mentally subnormel children incomplete unless it is followed up for at leest one term by the services of the psychologist who remains in and with the school to interpret the technical findings for the practical use of the special teacher.

In the school. where there is an established clinic, the records of each child are kept and added. In large cities reexamination of the

(28) Irvin, Mizabeth A, and Marks, Louis A. Eitting the School to the Child: An Exporiment in Public Education. Tho Macmilien Company. New York, 1924. 339 pp. 
mentality and achievement of all apecial class pupils occurs at regular intervals. Ner York City recomends reoxamination of all children in ungraded clesses at least once a term.

The need of vocational guidance is urgent for all mentally-reterded pupils for they can all be taught and helped to become self-supporting members of a comminity; some who are exceedingly capable mas assume positions of respongibility.

Ada Fitts $(29)$ claims that a child mas bo prepared for appropriate employment and mar be unsuccessful because of the lack of power of selfdirection and she urges that oversight and follow-up care be provided each mentally subnormal pupil who leaves tho school. She further ventures the opinion that the assumption of this responisibility for a year or two beyond the school time is just as much a proper function of the public schools as is the work with adults in continuation and ovening schools and centers.

Very few schools have any plan of follow-up to learn of their pupil's success or failure. Factories and business houses make surveys of their products but oducation just lets it's products fall where they may. Until some definite plans are made and carried out in a successful plan of follow-up procedure, a great neod in education will bo violated. Gesell(30) gives these five essentials of vocational after-care

(29) Fitts, Ade $U$. Hor To 7117 the Qep Botween Speciel Gasses for Mentally Defective Children and Institutione. Massachusetts Soclety for Mentel Hyglene, Bost on; 1926. 8 pe.

(30) Gesell, Arnold. Exceptional Ghildren and Public school Policr. Yale University Press, 1921. Ner Haven, Conn. $66 \mathrm{pp}$. 
and guidances

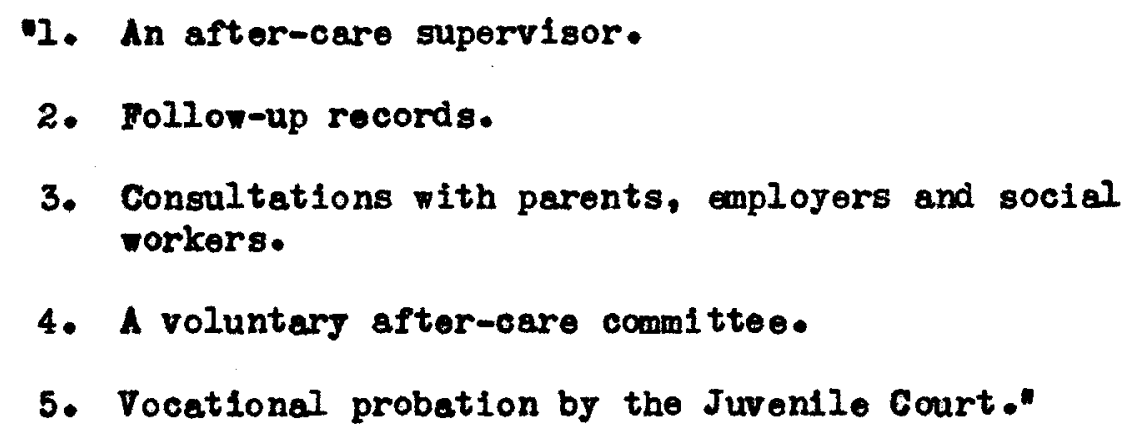

Perhaps money, interest of those who could help, facilities and manj othor factors have been the reason why plans similar to Gesell's are not more general.

In France, there is an out-of-school organization which visits the home and sometimes finencially alds the parents, and if necessary places the children in the country. When the child leaves school, this organization gutdes the child and his parents in a suitable occupation.

Descoeudres (31) states that both $\mathrm{gngl}$ and and France have after-care combittees. They help the child to acquire the right kind of a dob. and discourage the acceptance of any job which would be harmful to his morals or health. These committees appoint patrons to watch over the physical, mental and moral welfare of each individual, to contact the employers in regerd to working conditions and weges, and to help with financial assistance if the child is unable to support himself. That a follow-up plan is ossential to the mentelly-retarded is one of most vital points in the consideration of all administrators.

All of these factors, physicel environment, trained persomel, welldoveloped curriculum, vocational guidance and a definite follow-up procedure

(31) Descoeudres, Alice, Bducation of Uentelly Defective Children. Psrchologicel Observetions and Precticel sugsestions. D. C. Heath and Company, Nen York, 1929. $225 \mathrm{pp}$. 
have been disoussed with the view in mind that they are very definite problems facing the administrator of special classes for mentally-retarded children.

How the ohild is diseovered, diagnosed, assigned and then the method of administratian to which he is subjected can oi ther be a wasted and disestrous result or the proof of the Whitohouse Conference.(32)

"special Education of the mentally handicapped is not charity, but enlightened public policy, beneficial to society, as well as to the individual affected."

On the basis of this over-all picture of the maning of special Education, the miter shell attempt in Chapter III to give an outline of the trends and issues in the administration of the ungraded or special classes in the elementary schools of Louisville. Thereby laying the foundation for the study of the other cities in Chapter IV.

(32) White House Conforence on Child Health and Protection. Speciel Bducation, The Handicapped and the Gifted. P. 26. (Report of the Conmittee on Special Clesses) New York, The Century Co., 1931. 


\section{GHAPTIR III}

\section{A STUDY OF THE UNGRADED CLASSES}

IN THE DLARENARY SGHOOLS OF LOUISVILII 


\section{INTRODUCTION}

If our schools are to serve as information centers for simply teaching reading, writing and arithmetio with expansions of these basic tool subjects, then only one type of school is required throughout our country. However, if we as educators feel that this is not the school's purpose, but it is to serve as a place whorein boys and girls may IIve, were reading and writing and arithmetic are necessary tools for living. where guidence through teaching, through sharing experiences, through individual work for individual differences and special adjustment for all who need it then, and only then, does the school become a vital living place. Schools will be wade for children and not children for the school. This chepter shall attempt to convey some of the thoughts and trends on the administration of ungraded clesses prevalling now in the elementary schools of Louisville and to bring into view the paramount issues now before principals, teachers and administrators in Louisvillo.

\section{HISTORY OF THE FIRST MENTALLY-RETARDED CLASSES}

As early as 1913, the public school system of Loul sville attempted to fit the school to the child.

On November 4. 1913 in a three-story brick building neer Second and Gray streets a class for the mentally-retarded was formed. The first class contained four pupils to which was later added four Italian and three Russien children. The addition of these emigrant children to the claes proved to be an interesting ovent, as they shared experiences, language and stories with the other pupils.

During the year, forty children vere added to the cless enrollment at various times. Thoir chronological ages ranged from elght to sixteen. 
Their grades were from one through five.

Many of these children were four to six years retarded. The predominating reasons for their retardation were irregular attendance, mental retardation and the shifting of school attendance. Sane of these children had attended as many as six previous schools. The class had many who were misfits in the regular classrooms. They called the class the Unoede Mass' and the name had much appeal for the children.

In the mornings, reading, witing, and arithmetic vere taught and the afternoons were devoted to monuel training, which included besket weaving, sewing and needlework.

That firgt jear Binet tests were given and plans were mede to give psychologicel tests to all who entered after the first year. The year ended with an enrollment of seventeen. According to the Report of the Boerd of Bducation(1) the class which was under the direction of MissAlma Gooch was organized to give special attention to those children who had entered late or wo were unable to do the regular work in the classroom. The enrollment did not exceed more then twenty children at any time of the year and the children of forelgn element who attended the school because they IIved in the neighborhood remained in the class just long enough to learn something of the language then they were sent back to the regular class.

Mang of these retarded children were ten to fifteen years of age and would have been assigned to the first grade room if they had not hed the opportunity of belonging to the special cless. Many of these children

(1) Third Report of the Louisville Board of Education, fram July 1, 1913 to June 30, 1914. Published by Gross-Parson-Hemilton of Louisville, Kentucks, pp. 39-40. 
came from the mounteins and although they were ten to twelve years of age they had nover gone to any school.

The report(2) stated that eleven of these children that were in the first class were promoted, some for one-half a year's work and some for a year's work. The administrators vere so pleased with the success of the first class that they hoped to soon establiah twolve classes. In September. 1914 two classes wore establishod, one at the Duncan street school (now lonown as the Roosevelt School) and another at the Twelfth Ward School. The Duncan street School's class consisted of twenty-five children from nine to fourteen years of age in one grade while the Twelfth Ward School had nineteon children in the second, third, fourth and fifth greder. The superintendent of Schools, Dr. E. O. Holland was extremely Interested in these children and selected splendid teachers to guide them. Under his leadership, the mentally-retarded made great strides.

By 1918, there vere many additionel classes. According to the Bighth Report (3) the enroliment in all special classes had increased from trenty in 1912-1913 to six hundred and seventy-1n 1918-1919. Of this numbor five hundrod and fifty were listed as retarded. In 1917 three classes were established at the Hiram Roberts \$chool, one class for the first. second and third grades, another cless for the two divisions of the fourth grade, and another class for the fifth and sixth grades. In 1918 classes were formed at the Pinzer and Madison Street 8chools. The Duncan Street school now was known as theRoosevelt school and had increased to

\footnotetext{
(2) Ibld. p. 40

(3) Sighth Report of the Board of Aducation of Louisvil I0, Kr. From July 1. 1918 to June 30, 1919. Published by C. T. Dearing Printing Co. $189 \mathrm{pp}$.
} 
four clesses. One each for the two divisions of the second, third and fourth grades and one for both dividions of the fifth and sixth grades. There was an Atypleal Glass at the Second and Gray Street School and one class also at the Duncan Street School. A class was established for accelerated children at the Mary D. Hill school. This class was for both divisions of the fourth grade. There were three clesses for white boys who were behaviour problems at the Special School at Second and Grar Streets, and one for Negro boys at the Special Colored School at Thirteenth and Liberty. An opportuntty class had boen established at the Louisville Normal and a special class at the Children's Freo Hospital. Louisville was taking definite stops to provide for all its exceptional children.

The Elghth(4) report lists three classes of children as retarded:

1. Those retarded by nature but not foebleninded.

2. Those who have physical disebilities that hinder their mentel development.

3. Those who have had poor school privileges."

The board asked the help of the city for a special physician and marse. to care for these classes, and a mental test by the psychological laboratory. The report gives the result of a survey made of the Atypical Glass at the Duncen Street sohool and found that:

\section{9 were feebleminded \\ 15 were reterded \\ 2 were normel}

By 1928, some changes had taken place, some of theclasses had been discontinued and some added. According to the Eighteenth Report(5) there were the following classes for exceptional children:

\footnotetext{
(4) Ibid. p. 49

(5) Elghteenth Report of Board of Education of Louisville, Kre From July 1 , 1928 to July 1, 1929. Published by the Board of Iducation, Louisville, Ky. 44 pp.
} 
- Ingraded Class - Children's Freo Hospital

1 Class for Crippled Children - Baptist Hospitel

1 Class at the Kosair Crippled Children's Home

2 Classes, A and B at the Prentice School

5 Classes, A, B, C, D, E at the Hirem Roberts Sohool

5 Classes, A, B, C, D, E at the Roosevelt School

2 Classes for problem boys at the special school

1 Mass for problem boys at the Colored Special School"

By the year 1938-1939 there vere nineteen teachers of Ungraded Classes. According to the Twenty-Fighth(6) Report, the Ungraded Classes were listed as:

3 Classes A, B, C at the Lowell School,

4 Clesses A, B, C, D, at the Roberts school,

3 Classes A, B, C, at the Roosevelt School.

1 Class each at Atkinson, California, Dolfinger, Mary D. Hill. J. S. Johnson, Marshall, MaFerran, Morris, Prentice, Shameo and Washington schools.

1 Mass for Negro children at the S. C. Taylor School.

The Second and Gray school had been closed and class for problem boys was located at Parkland Junior High School. At the time of the Work's(6) Survey in 1942 there were approximately four hundred and fifty children in the schools sjsten's ungraded classes and fourteen teachers. According to the school direotory $(7)$ there were twelve ungraded classes for white children, one for colored and one class for special

(6) Norks, Dr. George A., Louisville Public School Surver. Published by the City of Louisvilie, KJ. 1943. p. 288.

(7) Directory of the Louisville Public Schools for 1945-1946, Published by Loulsville Board of Bducation. $267 \mathrm{pp}$. 
boys in the Louisville schools in theyear 1945-1946. From attendance figures received from the attendence Department there were $t_{\text {wo }}^{\text {nundred }}$ and twenty white children and twenty-oight colored children in ungreded classes in June, 1946.

\section{BXICENCY FOR CLARIFICATION OF FUNCTIONS AND PURPOSES OF UNGRADED CLASSES}

The ungraded classes are divided into two divisions consisting of two classes for special problom boys and thirteon classes for mentallyretarded and coach children.

The classes for special boys are arranged one for white boys and one for Negro boys. These classes consist of boys from the intermediate grades. The class for white boys are those of the cixth, seventh and eighth grades.

These special boys are behaviour maladjustments usually more advanced than the mentelly-retarded.

The ungraded classes for the mentally-reterded consist of one coach class in which the pup1ls recelve help in remedial work for part of the dey and spend the romaining part in a normal classroom; and twelve classes in which the children remein for a term, year or longer. One of these trelve classes is used for Negro mentally-retarded children.

11 though they are listed as ungraded classes for mentally-retarded, their personnel is composed of mentelly-retarded, mentally-backward, reading disability cases of normel mentelity and many discipline problems and misfits from normal classrooms.

According to a study made by Dr. George A. Workg(8) in 1942 of the

(8) Louisville Publio School Survey - A Report on the Public Schools of Loui svilile, KY. p. 289. Survey Mede by Dr. George A. Norks. Published b City of Louisville, Ky • 1943. 
Louisville public schools, "...there appears to be a need for organization In the special classes for mentally-retarded and their purposes of the class need to be known and its functions understood."

As a teacher of a class for mentally-retarded or ungraded class, the writer feels that there is a very definite need for clarification of what the class personnel should consist in order that a clear conception of an adequate curriculum and guidance plan for the class can be had. METHOD OF PROCEDURE

On the basis of this observation, and with a conceived plan for a national study of the tronds and issues in the administration of mentellyretarded children in the elementary schools, the riter planned a series of interviews with principals and teachers on the trends and issues in Loui sville.

The writer was aware that the subject of how tocare for mentallyretarded children both in the elementary and junior high school field was paramount in the minds of the administrative personnel of the Louisville public school system. The principels had discussed the subject in their meetings and committees were to be formed to study the problem. It hed also been discussed in some feculty meetings.

Cognizant of these proceedings, the writer felt that an understanding of the principal trends in Louisville and the issues involved in the admints- tration of mentally-retarded or ungraded clesses should be lucid. Therefore, the following topics were selected as the basis for the interviews:

1. Present type of classification of exceptional children.

2. Predominant issues involved in the care and administration of ungraded clesses.

3. Most general trends in Louisville. 
4. Basis for placement.

5. Inowledge before placement.

6. Administration plan for housing.

7. Curriculum

8. Guidanco

9. Follow-up procedure.

The seven principals and elght teachers who were interviewed were those who were teaching, had taught or were edministering ungraded classes.

In order that the one wo was interviewed might give some consideration to the points to be discussed, an appointment was mede several days in advance and certain factors were mentioned as possible topics to be considered. With an outline of several questions on each of the nine topics of interest on which to build the interview, notes were taken at each meeting. A list was made of all the expressed thoughts and views on each point of consideration and a consensus was formed of the prevalent trends and issues as each person sav and expressed them.

THE ACCEPTED FACT OBTAINED FROM THE INTHRV IEWS

As the interviews progressed, one fact stood out. We distinctly had in Louisville four definite types of children in our ungreded classes. Often all four appeared in one class. Without reservation it mav be stated that these four groups exist:

1. The mentally-reterded, 50-75 I. $Q$.

2. The mentelly-beckward or slow learner, I. 4. 75-89.

3. The cosch child - one with normal intelligence who needs remedial help in one or more subjects for a short period of time.

4. The socielly and emotionally unstable or malad justed. 
They are in the schools, and as the schools must fit the child, there must be plans made for his care.

\section{DIVERSIPICATION IN TRENDS AND ISSUES}

The trends in Louisville and the issues that confront the administrators are veried. Perhaps the importance that hes been given the study by principals in their meotings stresses the fact that the trends noed to be altered somewhat.

\section{DOMINANT ISSUES PRODUGHD}

These are some of the vital issues for the care of the mentallyhendicapped that were gernered through the interviews

1. What tjpe of ohild should constitute the membership of our ungredod classes?

2. If two groups are combined, which two Broups would produce the best results (ex. the mentally-retarded and the mentallybackward and the educationelly-backward)?

3. What is the best method of housing these classes, separate cless in different schools or a special school center?

4. What can be done to attract more experienced teachers to the fleld of speciel oducation for mentelly handicapped?

5. What should be the besis of transfor of a pupil from an ungraded class in the elementary school to the juntor high school?

6. What is the best plen of curriculum that can be offered these children in the Louisville schools?

7. How can we guide them so that they can take care of themselves in lifo?

8. How, in what was can a supervisor of special oducation best help the teacher of mentally-retarded children?

These are all issues offered by those who were intervieved. Most of them were thought of as questions for which suggestions were made as possible enswers. The vriter is not attempting to answer these problems or 1ssues, but is merely stating the issues and commenting upon them from 
facts gained bout them in the interviews.

The principels and teachers were in accord with the thought that the purposes and functions of the ungraded class should be better understood, and a clarification of its members should be made before an adjustment could be realized.

There wes an agreement by all that the mentally-retarded child should not be placed in the same class with the emotionelly unstable and the cosch child. The emotionally unsteble child or behavior problem is not assumed to be mentelly-retarded.

Baker(9) states: "Subsequent studies of behavior problems show the peak of distribution to be about I. $Q .85$ or in the slor-loarning group. The distribution tapers off both ways from this peak down to the feoblo-minded and up through the average group with a small number among the superior and gifted."

This child often takes too much of the teacher's time that should be spent in the interest of the mentally-retarded. The curriculum is not planned for him and, therefore, he 1s lost in the class. This brought out the fact that we need more ungraded clesses to take cero of the various types of exceptionel children who need our help.

As to the method of housing these children the principals varied in their opinions. There vere those who felt that in the elementary school the child should be kept in his own school or noighborhood, that each school that needed an ungraded class for the mentelly handicepped should take care of their own pupil rather than send the child to another location.

(9) Baker, Herry J., Introduction to Axceptionel Children, The Macmillan Compeny. Ner York - 1945. page 355. 
Because of the stigme that might be attached to a child who left his own school, it was thought that if he remained in the sohool it might go fairly umoticed by other pupils, parents and neighbors. It was also agreed that mentally-handicapped children are slow to adjust, and ther could do much better if they remained in their ow neighborhood, and a beliof wes expressed that a strange school with new teachers and new friends might develop a personality maladjustment demanding more individual attention.

Geveral endorsod the thought that four or five rooms in a specified school known as a special school center might prove to be more beneficiel. It would offor an opportunity to have more curriculum instructional materials, equipment and facilities; the child could come in contact vith more than one teacher; and a greater degree of homogeneity in the grouping could be had. Because of the greater number of teachers and facilities. there would be broader curriculum experiences.

The decision as to whether the slow-learner should remain in the regular class or whether ho should be placed in an ungraded cless was an 1ssue presented but not solved. The two prevailing thoughts were, if he is left in the regular class what plans can be made to care for his individual differences; if he is placed in a special class, what type of progran should be offered?

In the issue of basis for removal, three questions were considered,

1. Should a child be advanced to junior high school bocause of age?

2. Should grade achievement be the factor?

3. Should the junior high provide a progrem that carries on where the elementary school leaves off?

The Works(10) survey states that the entrance plan to the junior high

(10) op. cit.- p. 289. 
should be more flexible as many children have a very limited vocabulary and would be unable to make a satisfactory achievement grade.

Although these three questions were advanced, most of those who were interviewed agreed with the Survey that something should be done for the child who could not pass a satisfactory achievement grade. It was a vital issue but no recommendetions were mede.

Supervision proved to be an interesting point in the issues. It was en accepted fact that each principal believed that the average school princlpal was not qualified to superviso special classes for mentallyreterded. They expressed the belief that there was a definite need for a specially-trained supervisor or director of ungraded classes who should not heve any other duties. It should be the duty of that supervisor to obtain the needed supplies, books and materiels; also the supervisor should aid in the selection of teachers for ungraded classes, and should work with the teachers on a special curriculum. Paramount was the fact that the supervisor's first duty was to help and guide the teacher in her nork.

In relation to the ourriculum, the principals and teachers expressed a need for a special curriculum. They definitely stressed the fact that 1t was a vitel issue but were unable to offer a definite plan.

Manj suggestions were offered as an ald in forming a curriculum. Among them, these were offered.

1. It should be general; it should develop ettitudes, habits and some skills.

2. It should be as varied and as interesting a program as possible.

3. It should not be all drill subjects.

4. It should contain art and handwork. 
5. It should teach the fundementel issues of life, should teach the child to make his Ilfemore interesting and beeutiful.

6. It should contain a basic study of the use of the City's resources, the Generel Hospital, social agencies, and the study of the purpose of the resources of the City such as the Water Compeny. the City Market, the transportation system, and others.

7. It should instill within each child the spirit of achieving. There isn't any doubt but that a curriculum that attempted to bring about the philosophy expressed would do much to help in the adjustment of the mentelly-retarded child.

The need for guidence and a good follow-up procedure was stressed as an issue that should be met. As the classroom teacher is the chief agency for guiding the mentelly-hendicapped child, her success is largely conditioned by her training, by the belp she recelves from her supervisor, principal, visiting teacher, nurse and other agencies and by the degree of flexibility and freedom permitted in the classroom.

It was admitted that a procedure for a follow-up of all mentallyretarded pupils was needed but how to obtain it was not offered. PREVALENT TRENDS IN LOUISVIILE

In direct contrast to the issues that are being considered are the trends that are prevalent.

There is a tendency in Louisville to place in the ungraded classes the mentally-retarded, the mentally-backward and the emotionally unstable. is the Fork's survey(11) reports:

"Although essentially for mentally-handicapped children, there is evidence that the classes are used as stop-gaps for some of the misfits and discipline problems in the regular classrooms, until such a time as they can be excused from attendance at school."

(II) Ibid. p. 278 . 
As it was stated at the beginning of this chapter, there are thirteen ungraded classes in the elementary schools. These classes for the mentallyretarded consist of:

1. Four single clessrooms in separate elementary schools.

2. Three clesses each in two schools.

3. Two classes each in one school for white children and one single class in an elementary school for Negro children.

All of these classes are in schools in the more impoverlshed sections of Louisville. They are located in buildings wich are comparitively quite old. Although they are not placed in a discarded section of the building, they leave much to be desired in environentel outlook, facilities and equipment. When a child is placed in an ungraded class, certain requirements have been met.

1. The child has been referred to the Bureau of Research by the principal for the purpose of testing the child to be placed in the ungraded class.

2. The principal is aware of this need by:

$$
\begin{aligned}
& \text { a. Lists of over-ase chlldren in the school. } \\
& \text { b. Recommendations from the present tescher or } \\
& \text { previous teachers in relation to his achievement. }
\end{aligned}
$$

3. A family study has been made by the visiting teacher of the child's attitude at home, his habits, play, his family and thelr home conditions.

4. The child is tested by the psychologist at the Bureal of Research or at the school. The pupil is given an Intelligence test and an achierement tost.

5. His habits and atitudes are noted by the psychologist.

6. The psychologist makes the recommendation for placement and often recommends a talebinocular or similar tost.

7. The child is then referred to the supervisor of speciel education tho ellocates him.

This is the generel trend in Louisville although sometimes a child is 
placed in the ungraded cless without testing because the regular class teacher and the principal feel that the child might profit from the help be would receive in the special class or it might be that the child has just entered the school from the country and does not fit into a normel class situation.

Before a child onters an ungraded class, there are certain facts that are known about him. The principal and teacher know providing the child has been tested and has pessed through the usual procedure, his mental age, his chronological age, result of achievement test, knowledge gained from femily study, some of the child's difficultios and possible physical recommendations.

To these facts which are now prevalent in Louisville, the following suggestions were considered to be important by those who were interviewed:

1. A complete physical examination.

2. A report of child's emotional status (habits, interests, eptitudes and urmet noods.)

3. A teacher's statement regarding the chlld's habits for over a period of one semester.

In regerds to the teacher-personnel, curriculum, guidance and follow-up procedure much is left to be desired.

The trend in Louiaville is that no definite required speciel training is needed by teachers of mentally-retarded children. Their requirements are the same as those of normal classroom teachers. There is no inservice training given or required.

No planned curriculum is used in all ungraded classes. Teachers follow their own initietive in types of units to be developed.

Until this year, there was no offort made for planned supervision. 
There is now a supervisor of special education who hes been of great assistance to the teachers in sending them desirable books and materials. The supervisor is also planning to assist in guiding and developing a special curriculum for mentally-retarded clesses.

Outside of the guidence offered in the course of events in the clessroom procedure there is no pre-vocational guidence offered. The child who achleves a fourth grade reading ablitity and is fourtion years of age is permitted to attend Junior High school without plans being made to help him adjust himself. When a child leaves the class, unless he returns to visit the school, or friends or relatives tell what he is doing no other information is acquired of him.

These tronds are not all satisfactory and it is to be hoped that some issues become realitios.

\section{THE BEGIMNING OF A NBW ERA}

In 1942, it was reported that there was no one in Louisville definitely interested in the mentally-retarded child. During the past year, a supervisor of special education has been appointed. The teachers of ungraded class for the first time in many years have recsived any supplies, books or otherwise that have been of exceptional value to them.

This appears to be a boginning of great plans to come. With plans for classifying the mentally-handicapped and developing a special curriculum for them this coming jear, many tronds will change and manj issues confronted will become realities and trends.

It is the writer's hope that the facts gained in the report in Chapter IV will do wuch to assist in the development of the program for the mentally-reterded in the elementary schools of Louisville. 
GRAPTER IV

FIND INGS FROA THE NATIONAL QUESTIOMNAIR: 


\section{IMTHOD OF PROCWDUR:}

Beginning with a consensus of information roceived from the survey of the trends and issues in the administration of mentally-handicapped in the elementary schools of Louisville, a questionnaire was formed around a series of focel points. The following factors were considered vitally important in the National surver.

1. Membership. Types of pupils enrollod in ungraded or special classes.

2. Membership. Methods used in selecting pupils for placement in ungraded or special classes.

3. Membership, Required information on what is known of the child before he is admitted to the olass.

4. Housing, The arrangement of the ungraded or special classes in the scisool system.

5. Qualification of Teachers

Their training and requirements.

6. Supervision, Detalls of supervision of ungraded or special classes, including the duties of the supervisor.

7. Curriculum, The acknowledgement of a definite plan of curriculum, the aequirement of learning skills, the question of provision far the joung-dull child of the kindergarten, instructional methods and guidance.

8. Miscellan- Home visits, basis for transfer from uneous graded or speciel class to regular class, factors, maximum number of pupils and follow-up plans.

It is not the purpose of this particular study to determine the ideal situation but to find the trends el sewhere in the United States in order to be able to determine how Louisville compares and to suggest some recommendations that might be of assistance to those who administer 
ungraded or speciel classes.

The questionnaire was sent to forty ofties that according to the 1940 United stetes census report are comparable to Louisville. These cities selected ranged from those with a papulation of from two-hundred thousand to seven-hundred thousand. It is admitted beyond question that certain c1ties with a population of over a million inhabitents have very desirable plans for the care of mentally-handicepped children, but just as it would be unfair to compare Louisvillo's and New York's transportation facilities, so likewise would it be prejudicod to compare the edministration of mentally-retardod children in Louisville with that of New York or some similar city.

The questionnaire was sent to the director of research or if he was not avallable, to the superintendent of the school system of the cities selected except in a possible overlapping of two neighboring cities of the same population area. The survey covers the territory from Seattle, Washington to Miam1, Mlorida. Thus, the writer foels that an attempt has been made to get a clear consensus of the national picture of the trends and issues in the administration of mentally-retarded children in cities comparable to Louisville, Kentuckg. In evaluating the results of this surver, it is important to keep in mind that there could not be expected to be a full reply to the questionnaire. As it was sent out in the summer or vacation period, many administrators wore away from their offices, some, perhaps, were changing positions and were not fully quelified to answer all the questions of their new places. Agein some may have folt that they were too far removed from Louisville to be compared with it. Needless to say, all educators are constantly bolng asked to fill out questionneires, many receive three or four a day. It is asking quite a lot of them 
to use their time to $f 11$ out these blanks for people not oven in their own school system or state. Therefore, the writer is exceodingly grateful that eighteen out of the forty administrators were courteous and thoughtful enough to take the time to answer this questionnaire. Most of the cities that answered came from within a radius of fifteen hundred miles of Louisville. From such cities as Milwauke, Minneapolis and Grand Rapids in the North, Miami, Birminghem, Nashville and San Antonio of the South, Atlenta and Wilmington. Deleware in the Kast, Kansas City, Missour1; Des Moines and Denver in the Nest and Akron, Columbus, Cincinneti, Toledo and Indianapolis of the centrel area, these returned questionnaires have cone to help form a composite view of the national reflection.

\section{CLASS IFICATION OP F INDINAS}

Membership. In order that there would not be any uncertaintty in the mind of the questionnaire's recipient as to the writer's meaning of mentally-handicapped and the factors pertaining to their membership in spocial or ungraded clesses. Christine Ingram's(I) three point definition of the mentally-handicapped, which is accopted by educators as the closest thing to a nation definition, was offered.

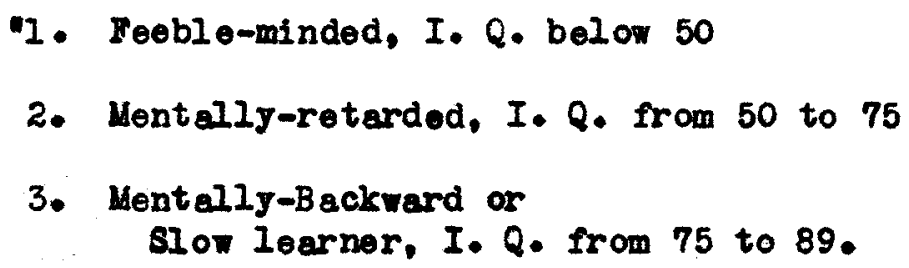

With these definitions in mind the recipient would be better equipped to answer the questionnaire.

Before the trends and issues in housing, teacher requirements,

(1) Ingrem. Christine. The Dducetion of the Slor-Learning Child. World Book Co., Yonkers-on-the Hudson, New York. 1935. pp. 5-7. 
supervision or curriculum could be ascertained, it was more essential to clarify the membership found in these special or ungraded classes. Therefore, the membership was divided into single, combined or composite groups including the mentally-reterded, mentally-backward, feeble-minded, emotionally-unstable, educationally-backward and any other plan that might bo used in the various school systems.

Table I gives the result of the types of pupils admitted to ungraded or special classes in the elementery schools in cities comparable to Louisville.

The regults show that the trend in the eighteen cities that replied is towards classes of mentally-retarded only or the combination of mentally-retarded and mentally-backward.

Most adinistrators hesitated to draw the line too closely. One of the plans disclosed that al though the clesses were for mentallyretarded only, there often was some modification allowing the admission of backward pupils with I. Q's of 75 to 79 if educational and social maledjustment fectors somed to wake it desirable.

Another notation inferred that although the clesses vere listed to Include the mentelly-retarded and the mentally-backward, it was not a rigid matter. In some cities, a few foeble-minded children wero included in the combination of mentally-retarded and mentally-backvard children. One school system whose four clesses were listed as for mentelly-retarded only stated that ten feeble-minded, twenty educationally backward and If fteen enotionally unstable chlldren were included in this group. Besides its classes for mentelly-retarded and mentally-backward only, Milwauke is exceeding fortunate in having four junior trade schools for unadjusted children over the age of thirteen and one-half jears. Two 
TYPES OF POPILS ADMTTTED TO SPECIAL OR UNGRADED

CLASSES IN THE BLAMTNTARY SCHOOLS

\begin{tabular}{|c|c|c|c|}
\hline & Type or types of children & $\begin{array}{l}\text { Nhumber } \\
\text { of } \\
\text { Schools }\end{array}$ & Percent \\
\hline 1. & $\begin{array}{l}\text { Only the Mentelly-reterded with I. Q. } \\
\text { of } 50 \text { to } 75 \text {. }\end{array}$ & 5 & 282 \\
\hline 2 & $\begin{array}{l}\text { The soentally-retarded and the mentally- } \\
\text { beckward. }\end{array}$ & 6 & $33 \%$ \\
\hline $3 \cdot$ & $\begin{array}{l}\text { The mentally-retarded, the mentelly- } \\
\text { beckward and educationally backward. }\end{array}$ & 2 & $11 \%$ \\
\hline 4. & $\begin{array}{l}\text { The mentally-rotarded, educationally- } \\
\text { backward, emotionally-unstablo. }\end{array}$ & 1 & $5.5 \%$ \\
\hline 5. & $\begin{array}{l}\text { Feeble-minded and the mentally- } \\
\text { beckward. }\end{array}$ & 1 & $5.5 \%$ \\
\hline 6. & $\begin{array}{l}\text { The mentelly-retarded, the mentelly- } \\
\text { backward and the emotionally-unstable. }\end{array}$ & 1 & $5.5 \%$ \\
\hline 7. & Al1 groups combined. & 2 & 21\% \\
\hline
\end{tabular}

of these schools are for the boys and two for the girls. The schools there also occasionally provide home teaching for a very emotionally unstable child. It would seem from the results obtained that many systems have too many tjpes of mentally-hendicapped chlldren and too few trained teachers and classes to supply the individuelized instruction that would like to give these children. 
MTHODS OF SHLCTION

After the mowledge of the types of pupils admitted in the ungraded or special classes was obtained, the manner in which the children were selected for placement was considered to be of great value. The methods suggested by verious educators and certain state legislations were used as the oriterie for judgment.

These fectors which were described in detail in Chapter II included intelligence tests, age-grade lists, psychologist's recomendetions, principals, teacher's recommendation and other evailable methods.

Teble II shors the manner in which the membership of ungraded or special classes vere obtained in these cities.

It is an interesting thing to note that every school system without exception gives and obtains the result of an intelligence test. Binet or simflar before placing the child in an ungraded or special class. That 77.7\% of the schools furnish a psychologists recomendation is outstanding. The recommendations of teachers, principals and visiting teachers are all quite evidently a factor in the nationel trend. The fact that $28 \%$ of the schools permit behavior problems to enter into the selections presents the viev that this is definitely an issue--should behevior problems, the emotionaly unstable be permitted in the membership of ungraded or specil classes? If not, how should they be taken care of? One system (Minneapolis) admits that if the child would benefit from the class instruction, he would bo recomonded for placement. Two systems (Mil weukeo and Kanses Gity, Missour 1) required the recomendetion of either a psychologist or psychiatrist before the emotionelly unstable is permitted to enter the mentallyhandicepped special class. Again are we taking care of the right child in the right place? 
METHOD OF SHLETIONS OF CHILDREN FOR PLACAMRNT

IN SFICIAL OR ONGRADED CLASSES IN BLEMENTARY SGROOLS

\begin{tabular}{|c|c|c|c|}
\hline & Method of Selection & $\begin{array}{l}\text { Number } \\
\text { of } \\
\text { Schools }\end{array}$ & Percent \\
\hline I. & Intelligence Test (Binet or similar) & 18 & $100 \%$ \\
\hline 2. & Age Grade Iist & 3 & $17 \%$ \\
\hline 3. & $\begin{array}{r}\text { Tears retarded }- \\
-1 \text { year } \\
2 \text { years } \\
3 \text { years }\end{array}$ & $\begin{array}{l}1 \\
2 \\
1\end{array}$ & $\begin{array}{r}5.5 \% \\
11 \% \\
5.5 \%\end{array}$ \\
\hline $4 \cdot$ & Psychologist's Recommendation & 24 & $77.7 \%$ \\
\hline 5. & $\begin{array}{l}\text { Behavior problems that upset normel } \\
\text { clessroom }\end{array}$ & 5 & $28 \%$ \\
\hline 6. & $\begin{array}{l}\text { Recomendation of last norwal class } \\
\text { teacher. }\end{array}$ & 7 & $39 \%$ \\
\hline 7. & $\begin{array}{l}\text { Recommendation of all previous } \\
\text { teachers }\end{array}$ & 6 & $33 \%$ \\
\hline 8. & $\begin{array}{l}\text { Recommendation of princlpal, visiting } \\
\text { teecher or parent }\end{array}$ & 3 & $17 \%$ \\
\hline 9. & $\begin{array}{l}\text { Request of parent or church school } \\
\text { Translents and Transfers from all } \\
\text { other systems. }\end{array}$ & 1 & $5.5 \%$ \\
\hline
\end{tabular}

A new note was entered in the selectlonal method when it was stated that transients and transfors from other school systems were candidates for placement in special classes.

The fact that church schools show an interest to request that a child be selected and placed is certainly a beginning of community interest 
and arereness of individual needs.

The method endorsed by Toledo, Ohio special education departments is that teachers and principal request a psychological test when the child does not appear to be making normel progress. Other children are found through a screening test given in the schools. The California Test of Mentel Maturity has been used often. Those appearing to be low or maledjusted are then given the Binet intelifence test. Placement is made after a consultation with teacher, principer and psychologist. All placement is mede by the supervisor of special education.

Required Knorledge. For each child that is selected and recommended for placement in ungraded or special classes certain information should be known not only by the administrators, psychologists, but also by the classroom tescher so that she may be aware of all the child's history. needs and potentialities. Among this information that should be factual lmowledge are the results of mental tests, achievement tests, physical examination, interest and eptitude tests and a school, home and family history. Table III presents the consensus of the information secured on what is known of the child before admittence to the special class.

On the basis of information contained in Table III it would be reasonable to say that the trends in required information to be knom of the mentally-handicapped child before placement in a speolel or ungraded class is unquestionably to know his mental ability, achievement from a standard test, the result of his physical examination, his school history and record, the records of his family history and heredity, of his environmental conditions, his emotional status and results of interest and aptitude test. The psychologist, principal, teachers and visiting teacher all 
INFORMATION REQUIRED TO BE KNOWN OF A CHTLD BEFORE

HE IS ADUITTED TO UNARNDED OR SPECIAL CLABS

\begin{tabular}{|c|c|c|c|}
\hline & Information & $\begin{array}{l}\text { Number } \\
\text { of } \\
\text { schools }\end{array}$ & Percent \\
\hline 1. & Mental ability & 18 & 100 \\
\hline 2. & Achievement from standard test & 18 & 100 \\
\hline 3. & Results of physical examination & 18 & 100 \\
\hline $4 \cdot$ & $\begin{array}{l}\text { School history including teacher's } \\
\text { recommendation }\end{array}$ & 15 & 83 \\
\hline 5. & Herodity and family history & 14 & $7 \cdot 7$ \\
\hline 6. & Bnvironmentel conditions & 14 & $\pi \cdot 7$ \\
\hline 7. & motional status & 14 & $m \cdot 7$ \\
\hline 8. & Interest and aptitude test & 11 & 61 \\
\hline 9. & Court Record & 1 & 5.5 \\
\hline 10. & Anecdotal records & 1 & 5.5 \\
\hline 11. & Personality characteristics & 1 & $5 \cdot 5$ \\
\hline 12 & $\begin{array}{l}\text { Clearance from social service } \\
\text { exchange }\end{array}$ & 1 & 5.5 \\
\hline
\end{tabular}

contribute in the acquirement of information in regards to factors five through elght. In Table III again can be noticed the use of outside services in acquiring information. this time the court and the social eervice exchenge are used. 
Housing. After the child has been selected, tested and recommended for placement, the administrative factor of housing becomes of paramount importance. Not to be cast off in a dingy disoarded section of the bullding but to be housed in pleasing enviromentel conditions that is the only way we cen help the ungreded or defective child.

Bender(2) states: "our best ecucational methods and facilities of all sorts, as well as an all-out human response, are for the exceptional rather than for the average chlld.

The ungreded or retarded child for example must have an extra budget for specially trained teachers, smell classes in good enviranmental conditions, spocial materials, project system of education and so forth."

Table IV shows the housing arrangement prevalent in these oftles. One fector brought out by the survey was that no school system had special clesses in every elementary school. It may be pointed out that half of the school have one class in certain schools and two or more classes in others, this arrangement of course depends upon the need. Only one city, Mlami, cleimed a special school center only. The three cities that stated that some children remained in the regular classroom admitted that it was usually because of limited facilitios or the lack of trained teachers. Nilmington. Delaware has also a remedial reading class in which the child spends one period in the morning in reading and one period in the afternoon in speciel shopwork. As stated proviously in this chapter. Milwaukee has also four juntor trade schools, two for bogs and two for girls over thirtoen and a half years of oge. Many systems have plens also for juntor high schools but they are not included in this study.

(2) Bender, Lauretta - Neuropsychiatric Contributions to the Mental Hyglene Problems of the Ixeeptional Child, "Mental Hygiene. Vol. 26, Oct. 1942. p. 619. 
HOUSING ARRMNGEMENT IN THE ELEMENTARY SGHOOLS

FOR SPECIAL OR UNGRADED CLASSES

\begin{tabular}{|c|c|c|c|}
\hline & Arrangement & $\begin{array}{l}\text { Number } \\
\text { of } \\
\text { Schools }\end{array}$ & Percent \\
\hline 1. & $\begin{array}{l}\text { One class only in certain elementary } \\
\text { schools. }\end{array}$ & 4 & 23 \\
\hline 2 & $\begin{array}{l}\text { Several classes only in certain } \\
\text { elementary schools. }\end{array}$ & 1 & 5.5 \\
\hline 3. & $\begin{array}{l}\text { One class in some schools, two or } \\
\text { more in others. }\end{array}$ & 9 & 50 \\
\hline & $\begin{array}{l}\text { One or more classes in some schools } \\
\text { and a speciel school center. }\end{array}$ & 3 & 17 \\
\hline $5 \cdot$ & Special school center only. & 1 & 5.5 \\
\hline 6. & Children left in regular classrocm. & 3 & 27 \\
\hline
\end{tabular}

Quelifications of Teachers. Every child, especially the mentallyhandicapped requires a teacher who is interested in developing him into a self-sufficient individual. A specially trained teacher who understands the psychology of the subnormal child would prove an asset to every department of speciel education. In Chart I will be found there is a definite need for more attention to be given special cless teachers by colleges, state universitios, state and local departments of education If we are to have fully trained teachers.

According to this Chart just a fraction over three-fifths of the special or ungraded classes in these cities have specially trained teachers. We do not put kindergarten teachers in junior high school, 
CHURT I

RXPERSSED IN PERGENTHCES

SCHOOL SYSTEMS THAT REQUIRE SPECIALLY-TRAINED

TEACHERS FOR UNGRADED OR SPECIAL CLASSES

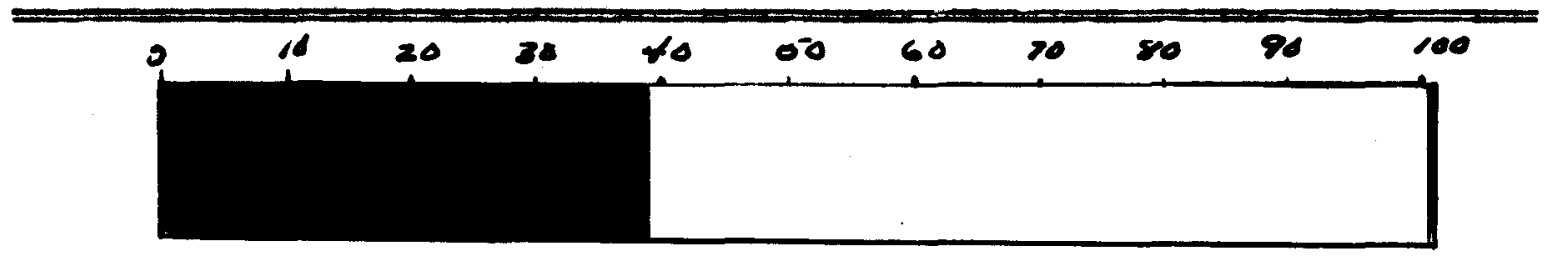
(7) $39 \%$
(21) $61 \%$

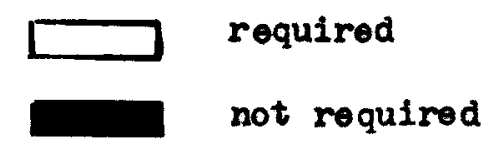

therefore, somewhere along the way someone has failed to provide for teachers who are interested in helping these mentally-retarded children. Most universities and teacher training schools did not and many still do not offer classes for the training of teachers of mentally-handicapped children. Therefore, it is a regretable circumstance and edministrative officials In the various cities should not be criticized too harshly. Milwaukee makes a demarcation between its teachers of mentally-retarded children and the teachers of the mentally-backward. Those who teach the mentallyretarded must be specially trained and are required by the state to have a certain number of hours of specialization. They must al so have experience with primery classes. This applies only to the teacher of the mentally-retarded child. Seven school systems have in-service training for teachers. In this group. Milwauke in connection with the state Teachers College in that city. The college offers as a part of its college course, a class in psychonetrics. 
Other requirements which administrators desire for their special class teachers include, enotional stability, interest for the rork, primary training, fitness as to personelity, the requirements of a regular classroom teacher, and interest in the backward child.

Most states do not require a certain nuber of hours of spocialization at present, but it will soon be effective in meny places. It wes steted by several administrators that because of the shortage of teachers and the scercity of courses in this fleld being offered by colleges and universities, they could not be too rigid in their requirements at the present time. Meny states are working tow ards the goal where a cortain number of hours of specialization will be required. Delavare now requires twenty-four quarter hours and Minnesota twenty quarter hours.

\section{Supervision. In harmony with effective teaching by trained} teachers goes cooperative, helpful, productive supervision by trained supervisors. Chart II shows that there are more cities that have a specially-trained supervisor.

GHAR IT

\section{EXPRTSSED IN PERCDNTACHS}

SGHOOL SYSTYMS THAT HAVE A SPECIALCY-TRAINED

SUPBRVISOR FOR ONGRADED OR SPECIAL CLASSES

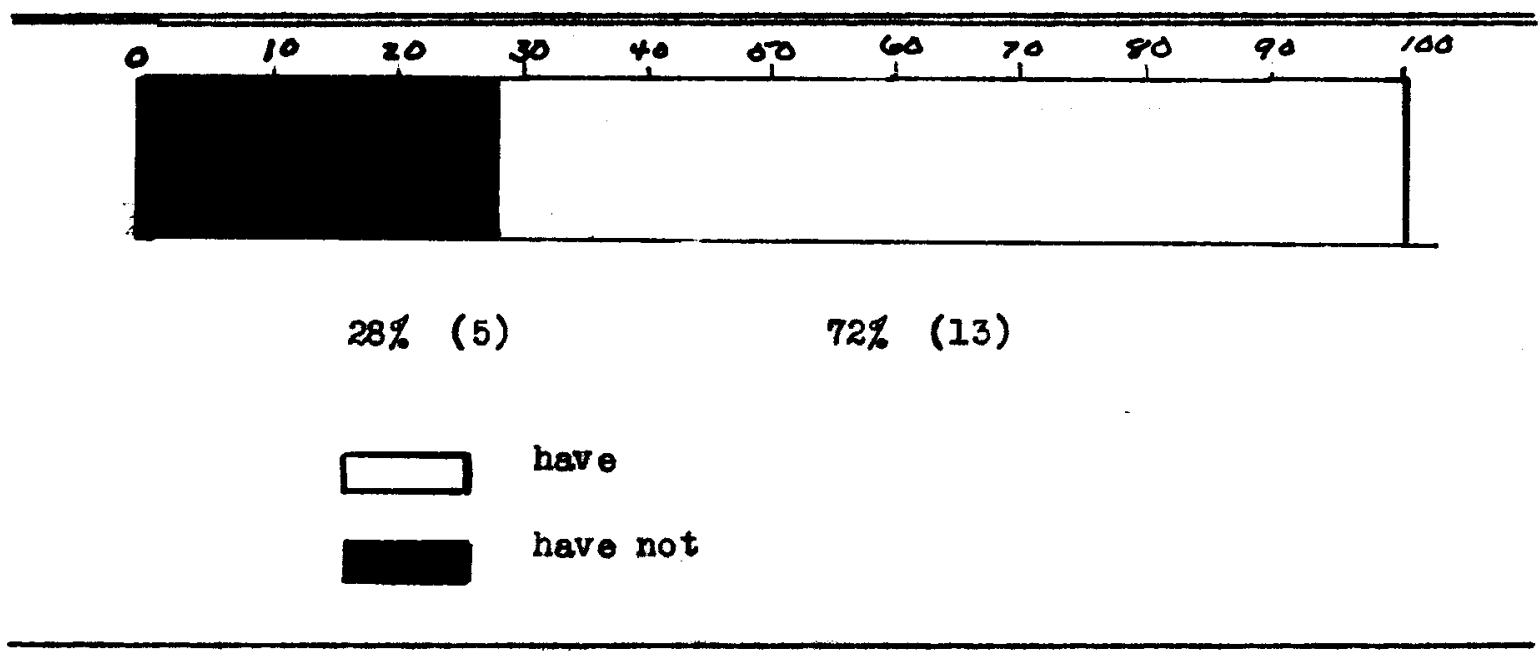


Although there are seventy-two percent of the supervisors speciallytrained for work in special education, many of them have other duties then the supervision of mentelly-retarded clesses. In Table $v$ will be found a sumary of these duties.

TABLA V

DUTITS OF SUPTRVISOR OF UNCRADED OR SPECIAL CLASSES

\begin{tabular}{|c|c|c|c|}
\hline & Duties & $\begin{array}{c}\text { Number } \\
\text { of } \\
\text { Cities }\end{array}$ & Percent \\
\hline 1. & $\begin{array}{l}\text { Supervises mentally handicapped children } \\
\text { only. }\end{array}$ & 4 & 23 \\
\hline 2. & $\begin{array}{l}\text { Supervises all classes for handicapped, } p \\
\text { physical and mental. }\end{array}$ & 6 & 33 \\
\hline 3. & $\begin{array}{l}\text { Director of Curriculum and Guidence } \\
\text { Center. }\end{array}$ & 1 & 5.5 \\
\hline 4. & $\begin{array}{l}\text { Supervisor of Kindergarten Intelligence } \\
\text { test and all handicapped classes. }\end{array}$ & 1 & 5.5 \\
\hline 5. & Aid in Construction of Curriculum & 12 & 67 \\
\hline 6. & $\begin{array}{l}\text { Princlpal of school and director of all } \\
\text { pupil personnel }\end{array}$ & 1 & 5.5 \\
\hline 7. & $\begin{array}{l}\text { Camplete charge of all instructional } \\
\text { materials and supplies }\end{array}$ & 5 & 28 \\
\hline 8. & $\begin{array}{l}\text { Partiel charge of instructional materials } \\
\text { and supplies }\end{array}$ & 8 & 44 \\
\hline 9. & $\begin{array}{l}\text { Aids in the nomination and selection of } \\
\text { teechers. }\end{array}$ & 11 & 61 \\
\hline
\end{tabular}

It can be noted that there are more supervisors whose duties include that of supervising all types of handicapped children rather than mentally- 
hendicapped alone. Beside the actual supervision of these classes, the two most prevalent duties are: alding in the oonstruction of the cur riculum and in the nomination and selection of teachers. This is followed in importance by the partial charge of selecting instructional material and supplies. In this work she is helped by various persons. In wilmington, the assistant superintendent in charge of elementary education, the executive secretary of the chlld study group and the principels of the various school afd her. In Minneapolis, Columbus and Birmingham, the assistant superintendent and the teachers aid in selecting the supplies. It is surprising to find that five schools hove supervisors that have complete charge of the selection of instructional materiels and equipwent. The teacher and her class are the users and as Patey(3) states: The focal point of the school work is the classroom, with the teacher serving as the practitioner."

In medicine the practitioner consult the specialist for help. they work together. This is true not only in medicine, but in education and other things, and it stands to reason that a good teachor is able to assist the supervisor in her selection.

Curriculum. The mentelly handicapped child who has been selected. tested and placed in a classroom is still the same child who was taken from the normel classroom unless there is a definite plan developed to help him in the new class situation. He needs social adjustment as vell es mentel. He needs to acquire that feeling of "belongingness" that sense of being one of the group before any attempt of mental adjustment mes be mado.

(3) Patej, Hemy C., The Teacher as a General Practitioner in Mentel Hygiene." Mental Hrgiene, p. 611. Oct., 1940. 
In these classes, the old academic type of program must change to a curriculum which relates the subject matter to real life problems of boys and girls. With these thoughts in mind and the knowledge that the director of special ecucation is planning to construct a new ourriculum for the mentally-handicapped children of Louisville, the writer desired to learn how many cities had a spocial plan of curriculum.

\section{CHART III}

IFPRDSSED IN PERCENTACAS

CITIES THAT HAVE A DRFINITE PLAN OF CORRICULW

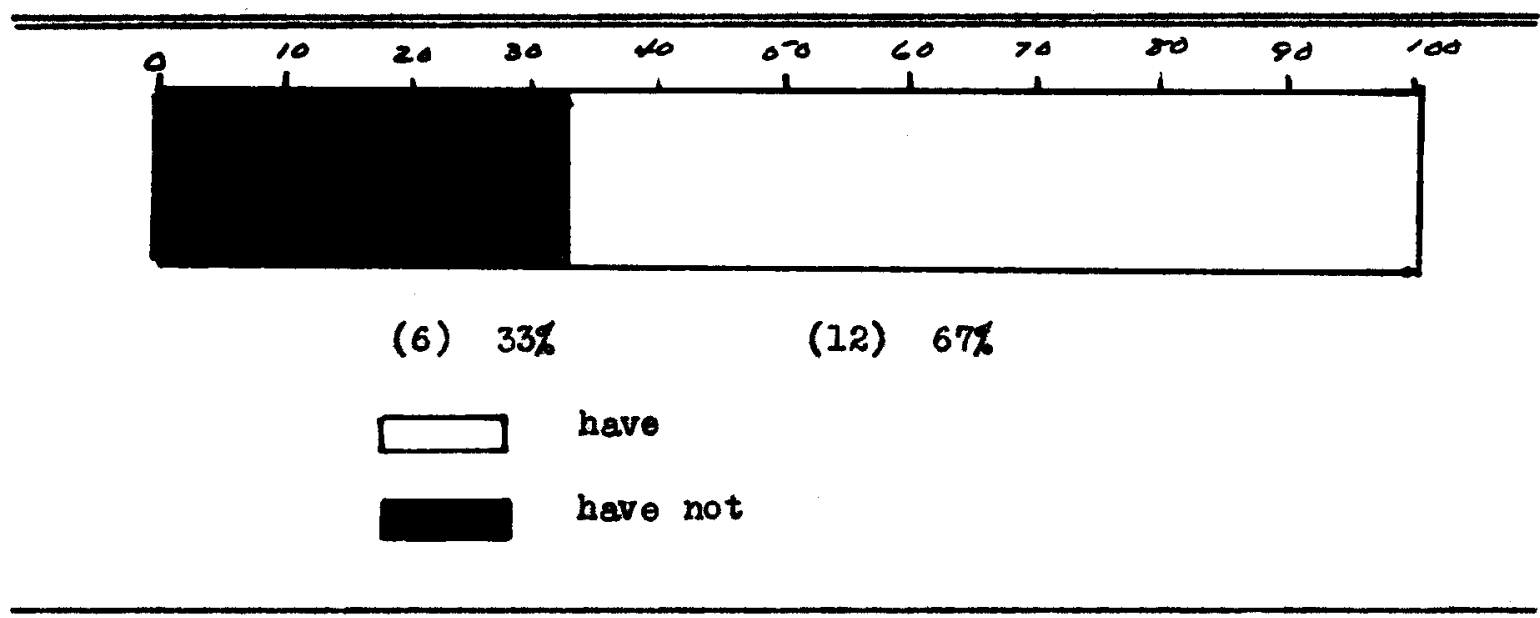

That two-thirds of the cities had a definite plan of curriculum was encouraging and several stated that they were working on one at the present time.

Three of the school systems that have a definite plan state that the curriculum is somewhat modified from the regular course of study.

Although the riterdid not ask for the plan of curriculum as administration was the main topic, nevertheless, there was a desire to include same fectors in information desired of the curriculum. These are listed in Table VI. 
A curriculum in wich little emphesis is placed on the integretion of academic experiences with Iffe situations is of Iittlo use to the mentelly-retarded. Tew curriculums offer adequate experiences in social ad Jus tment.

According to Martens(4) the only was to build a curriculum is to build it on experiences of the child.

"Build it on thechlld's experiences, the srowing ability to work and play with companions; actually to propare food and clothing for use; to spend money for necessities, and to master the skills that are needed for carrying out in reality the needs of his daily ilfe.

...The "unit experlence" is introduced in order to facilitate the organization of experience at levels at which they are most efficacious in the child's living. The unit of experience may be defined as an actual experience in living related to the child's immediate interests and enviroment, which in turn related to his total experiencesmeke for richer and more vital living."

These experiences are to the mentally-retarded child very real. They help him to live and work withothers and to satisfy his mental. physical and sociel needs. The neods of these children must be acknowledged and the curriculum planned accordingly. Therefore, the information acquired In Table VI was considered ossential.

It can be confirmed that shopwork and handwork are definitely a part of the curriculum when ninety-four percent of the schools use them. Activity units form the basis of the acadenic experiences and learning is acquired through plannod work with these activities or by drill work at

(4) Martens, Elise H. A Guide to Curriculum Development for Mentellyretarded Chfdren. D. S. Office of Iducation, Washington, D. C. 1936 - No. 11, p. 30 . 
INFORMATION DESIRED REGARDING THE CURRICULUM OF SPECIAL OR UNGRADSD CLASSES FOR MENTALLY-RETARDAD

\begin{tabular}{|c|c|c|c|}
\hline & Factors Considered & $\begin{array}{l}\text { Number } \\
\text { of } \\
\text { Schools }\end{array}$ & Percont \\
\hline 1. & $\begin{array}{l}\text { Learning acquired through a program of } \\
\text { varied topical activity units. }\end{array}$ & 14 & $77 \cdot 7$ \\
\hline $2 \cdot$ & $\begin{array}{l}\text { Curriculum includes making child araro } \\
\text { of the facilities of the city. which } \\
\text { are his to use now and as an adult. } \\
\text { (ex. T. Beline, social agencies.) }\end{array}$ & 12 & 67 \\
\hline 3. & Curriculum includes shop work & 27 & 94 \\
\hline 4. & Curriculum includes handwork & 17 & 94 \\
\hline \multirow{4}{*}{$\begin{array}{l}5 . \\
6 .\end{array}$} & $\begin{array}{l}\text { Curriculum includes a guidance } \\
\text { plen to help child select later } \\
\text { employment. }\end{array}$ & 9 & 50 \\
\hline & Learning skills are acquired. & & \\
\hline & 1. Incidentally through activity & 7 & 39 \\
\hline & $\begin{array}{l}\text { 2. By drill work at spocific } \\
\text { times. } \\
\text { 3. By plenned work with activities }\end{array}$ & $\begin{array}{l}13 \\
13\end{array}$ & 72 \\
\hline $7 \cdot$ & $\begin{array}{l}\text { Gurriculum includes a plan for the young- } \\
\text { dull child who cannot adjust in Kinder- } \\
\text { garten. }\end{array}$ & 1 & 5.5 \\
\hline
\end{tabular}

special times. The fact that sixty-seven percent of the schools are making the child aware of the city's facilities that ore there for him and his family to use is very commendable. Every child should have the advantage of tubercular tests and the knowledge that his family may 
receive them also is a factor of physical health that certainly should not be overlooked.

It has been stated that the earlier we detect the mentallyhendicapped child, the sooner we can help him.

Manj children are unable to succeed in kindergerten beceuse they are slow and "Iumbering" and do not adjust well socially. It is unfortunate that only one school system, Akron, Ohio, has any provision made for these children.

Most administrators were not specific in the amount of time devoted olther daily to handwork or weekly to shop work. Scme had alternating days for shop and handwork. The age of the children involved entered into the time schedule. Handwork varied from an hour a day to three hours a dey and shop work varied from one hour to ten hours a weok. Milvaukee divides its shop work into one to two periods a week for the mentally-beckward and two to five periods a week for the mentallyretardod, while a helf a day is devoted everyday to handwork for the mentelly-retarded and thirty to forty-five minutes a day for the mentallybackward.

Half of the schools admit that they do not have a gutdance plan. These children noed guidence to find and to choose occupations in which they have a reasonable chence of holding a job and earning a living. They need help in plenning their leisure time. Guidence is a part of the education of all excoptional children. Wo mast heve a progrem of guidance to serve the mentally-handicapped through school and into adult 11 fe.

In the use of instructionel materials and methods in the special 
classes Table VII shows the types used and percent of their usage.

\section{TABLP VII}

INSTRUCTIONAL UETHODS USED IN SFTCIAL OR UNGRADED CLASSES IN FHEMENTARY SCHOOLS

\begin{tabular}{lcc}
\hline \multicolumn{1}{c}{ Wethods Used } & $\begin{array}{c}\text { Number } \\
\text { of } \\
\text { Schools }\end{array}$ & Percent \\
\hline 1. Excursions & 14 & 77.7 \\
2. Motion Pictures and Visual uids & 18 & 100 \\
3. Construction of friezes & 12 & 67 \\
4. Construction of models & 11 & 61 \\
5. Construction of displass & 12 & 67 \\
6. Construction of charts & 15 & 83 \\
7. Visit to smell shops and industries & 12 & 67 \\
8. Bepresentatives of various vocetions & 8 & 44 \\
\hline
\end{tabular}

Motion pictures and visuel aids vere more universelly used then any other means. In some place they are used two or three times a reek. Most schools emphasize the use of excursions and visits to smell shops and industries although they stated that because of the var they were limited as a result of transportation difficultios. The construction of charts, models, displays, friezes, were quite prevalent.

Miscelleneous Factors. In regards to home contacts, the visiting teacher and the social sency worker were the visitors in the majority of cities. The classroom tescher could visit in the home if she desired but 
only in the three cities of Grand Rapids, Columbus and Hiaml are the teachers required to visit each home in order to understend thehomebackground.

The maximum number of pupils found in ungraded classes are shom in Chart IV.

CHART IV

RIPRESSED IN PERCENTAGES

MAXTMOM NUTBER OF PUPIIS PAR TEACEER OF THE

UNGRADED OR SPECIAL CLASS IN THE ELTMERTARY SCHOOL

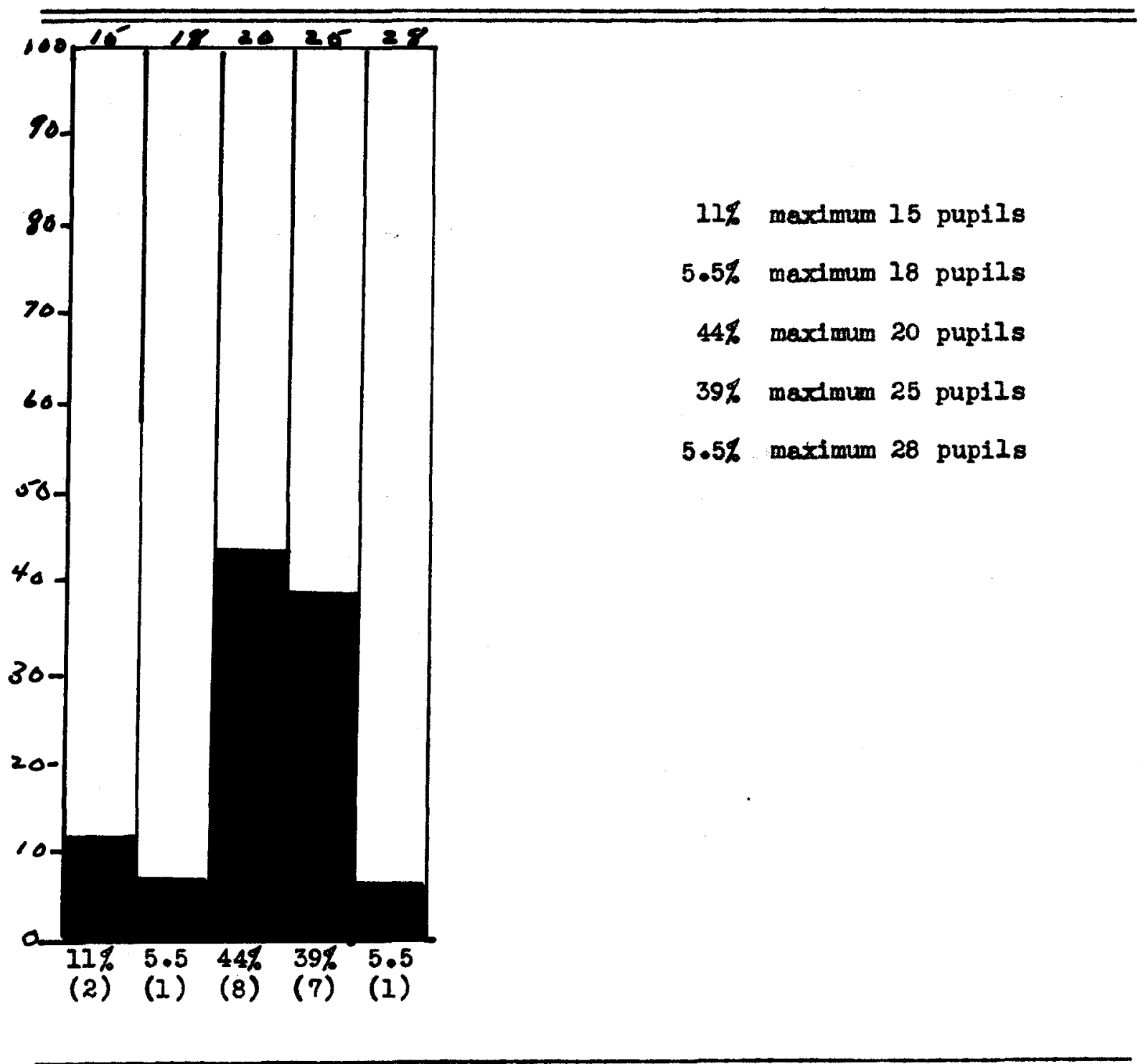


Although occasionally the number varies, the number indicated are the most acceptable maximus desired. It can be seen that there is little variance between the trenty and twenty-five pupil arrangement so the trend appears to lie within this range.

In stating the basis for transfer from the ungraded or special classes, the following factors were listed as reasons for the transfor of a child to a normel class. These incluaed ago, reading, level, general achievement and adjustment, child welfare and the recommendations of the tescher.

General achievement and adjustment endorsed by the psychologist and teachers recommendation was the basis for transfer given by seven school systems; reading level was considered important by six systems; recomendations by the teacher, size and age were used as a basis by three and three did not state their reasons. Thether these remeining schools considered all these points cannot be determined, but it is safe to say that general achievement and adjustment as determined by the psychologist and the teacher, and a reading lovel of perhaps the fourth grade may be considered close to the trend endorsed by this group of cities.

Follow-up Plense According to the Educetional Policios Commission(5) "The school of the future must be focusod upon the particular noed. through guidence and a flexible progrem for speciel provisions for the mentally-handicapped and must offer services that will follow the youth from his school Iffe to adult life."

(5) Educational Policies Commission. Education for Ml-American Youth. Washington, D. C. - 1944. p. 335 . 
Yet from this questionnalre, it may be gleaned that only fifty percent of the schools have guidance plans and Chart $V$ will show that fewer schools have follow-up plans.

\section{CHART V}

\section{EXPRTSSED IN PWRGANTAGWS}

CITIES THAT HAVE A FOLLON-UP PLAN FOR THE MANTALLY-RWARDED PUPIL ATTER HE LEAVES SCHOOL

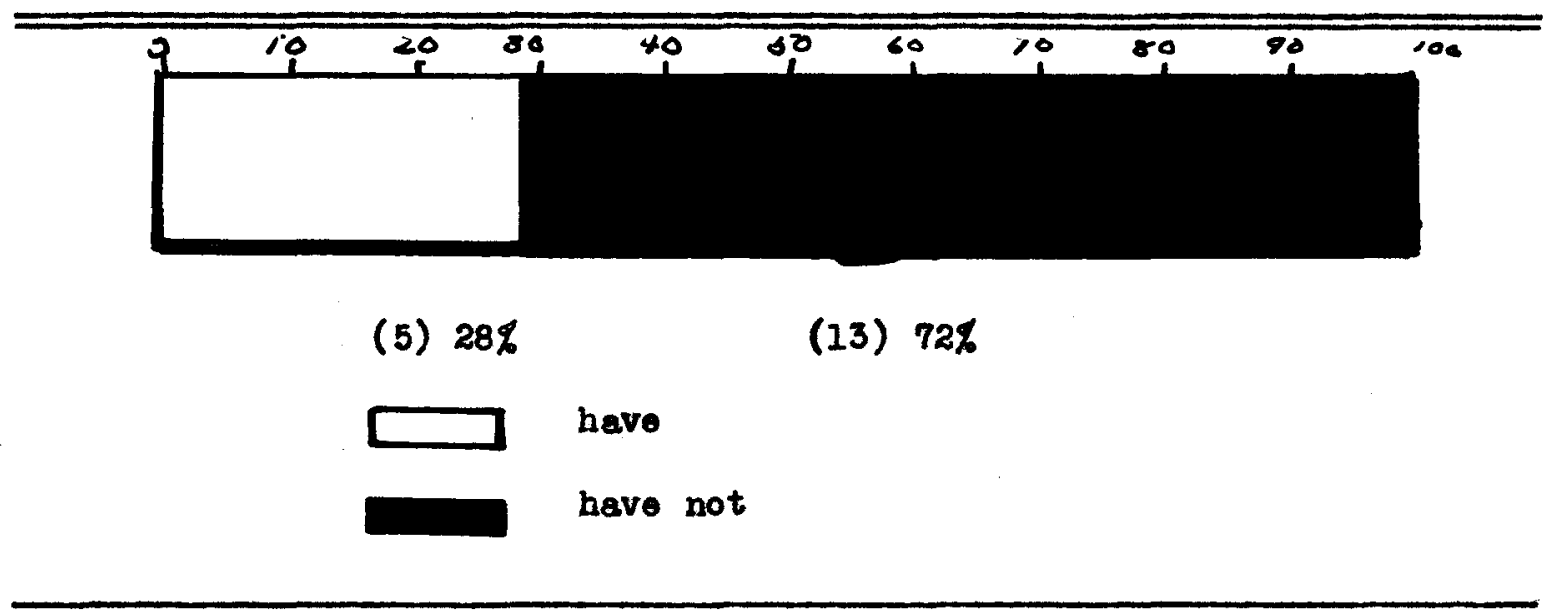

Of the twenty-elght percent that have follow-up plans not two of them are at all similar. Miami has a follow-up plan in connection with the Miani Socioty for Special didts.

Des Moines has a cooperative plan with State Department of Vocational Rehabilitation.

In Birminghem, if the child remeins in the school system, the visiting teacher may follow-up the pupll at the request of the principel or regular teacher.

In Milwaukee most of the chfldren enter the vocationel schools from the junior trade schools.

The Department of Research and Guidence in Atlanta appears to have 
a well-thought out questionnaire to aid in curriculum and guidance. The questionnaire which is really a large follow-up card contains many points of interest to the reserach department. Among the details included are; pupil's neme, address, telephone number, the seme of his parents Training Data, the schools, institutes, colleges that the pup1l attends, the date of entrance, reasons for leaving, diplome or certificate that he mar recelve, the listing of any informal in-service training and a full record of his employment. The card also includes space for personal statements in regards to his feelings toward his job, eny help that he could have received at school that would have benefited him, and a summary of things that he learned at schoolthat did help him.

Throughout this chapter the writer has attempted to bring out the results of the questionnatre as clearly and concisely as possible. It should be stated that each school system is one unto itself and there cannot be expected to be aniformity of purposes, mothods, reasons or judgments. Since it is impossible to evaluate the helpful and the hinderIng efforts of all the points of administration of mentally-retarded children in the elomentary schools in Louisville and other comparable cities, it is to be hoped that the interpretations of the survey given in this study will be regarded as primerily tentative and subjective. Throughout the findings from the questionnalre, certain definite trends have been prominent.

8ummery. Although it was not possible to obtain a complete consensus of information, the finding are considered sufficient hovever to indicate that there are a large muber of administrative trends. They undoubtedly have an important bearing on the education and training of 
the mentelly-handicapped children in similar citles trends are generally considered the results of educational policy, administrative functions, finance and interest of the city and state.

Obviously in those cities where economic levels are inadequate, there cannot be the right provisions made for the mentally-handicapped child, and in those states aided by state funds exceptional work is being done. As a result, all school systems vary in the problem of caring for the subnormal child. The general trends often change and there shell appear from time to time a need to have another survey. Tronds in the Group of Cities. At the present time, according to the answered questiomaires, the principal trends in the adinistretion of classes for mentally-hendicapped children in elementary schools for cities whose population ranges from two-hundred to seven-hundred thousend people appear to bes

\section{Nembership of Class}

1. To establish classes for mentally-retarded only.

2. To establigh classes for mentally-backward only.

Although this is not a too rigid enforcement, and it permits the size of the enrollment, number of teacher-personnel and housing to effect the distribution in the class.

\section{Nethod of Selection.}

1. By the use of Binet or similar intelligence test.

2. By the recommendation of the psychologist.

3. By the recomendation of the principal and the teachers.

III. Required Information

1. The knowledge of child's mental ability.

2. The result of the achlovement from a standard test. 
3. The result of a physical exanination.

4. A complete record as much as is obtained of the child's heredity and famliy history, the environmental conditions, omotionel status, interest and aptitude test and a complete school history including the teachers' statement about the child's habits.

IV Housing

1. To have one or more classrocms in certain schools where they are needed.

V. Quelifications of Teacherg

1. To have the teachers specielly-trained in the education of the mentally-handicapped child.

2. To have teachers pessess certain requirements; interest in her work, personality, emotional stability and successful elementary experience.

3. Toward obtaining classes for inservice training of teachers.

4. Toward the establishment of a state requirement of a certain number of hours of specialization.

\section{Supervision}

1. To have the supervisor specielly-trained in speciel education.

2. To have the supervisor supervise all classes of exceptional children.

3. To have the supervisor aid in the construction of the curriculum.

4. To have the supervisor have partial charge of the selection of instructional materials and supplies.

5. To have the supervisor aid in the nomination and selection of the teachers of special education.

\section{Curriculum}

1. To have a definite plan of curriculum.

2. To have the curriculum mede up of various topical activity units.

3. To have the child aroused to the use of the city's facilities. 
4. To include shop work and handwork in the curriculum.

5. To formulate a good guidance plan.

6. To have loarning acquired through planned work with activitios and drill work at specific times.

7. To frequently use visuel aids and motion pictures.

8. To visit industries and small shops and take trips.

9. To construct cherts, models, friezes, and other explenatory means.

\section{Miscelleneous Factors}

1. To have the visiting teacher with the aid of sociel workers as the connection between the home and school.

2. To have the maximum number of pupils a variance between twenty and twenty-five.

3. To have general achievement, adjustment and a recommendation by the psychologist and the teacher as a basis for transfer from the ungraded or special class.

4. Not quite so decided a trend is the one in which reading lovel is used as a basis for transfor. 


\section{CHAPTER V}

A SUMMARY OF THE ISSUES INVOLVED AND SOUB SUGGESTIONS 
Just as the trends give the present picture there is the possibility that issues present the one of the future.

From the results of this study, the witer feels that the following are the predominant issues in regards to the edministration of mentally-handicappod children.

\section{ISSUES}

1. How wide can the Iine of demarcation be drawn between members of mentally-handicapped classes and still have them serve their rightful purpose?

2. Should behavior problems, the emotionally unstable child or the misfits in the classroom, be permitted to become a part of the mentally-retarded or mentaliy backward class?

3. Should there be laws in each state to exclude the feebleminded from public schools?

4. How early should a child be placed in an ungraded or special class?

5. If an age-grade Iist is used, what should be the basic number of years of retardation?

6. How much should outside influences including; court, church, social agencies affect selection and plecement in spocial classes?

7. Whatis the best method of housing mentelly-handicapped children, separate classes in certain schools or a speciel school center?

8. What is the best manner of supplying in-service training of teachers?

9. When shall it be acquired, during the vacation period, after school hours, or Saturdays?

10. How much of a load or mmber of duties should a supervisor have?

11. How much weight should her opinion count in the nomination 
and selection of teachers?

12. What constitutes a good curriculum?

13. How much time should be devoted weekly to shop work, daily to handwork?

14. What is the best method of guiding a mentally-handicappod child to insure a self-sufficient future? (guidence plen).

15. How are skills best acquired by mentally-bandicapped children:

16. What provisions can be made for the young-dull child of kindergarten age?

17. What should the maximum number of pupils in special classes In order to give the right attention to each child be?

18. Whatis the best basis for transfer?

19. What constitutes a good follow-up plan and how can it be best executed?

The trends vere discussed quit te fully in Chapter IV and an attempt to solve the issues rould constitute a study in itself. The writer believes that the results of the questionnalre have been exceedingly helpful in ostablishing the trends and pointing out the issues in the administretion of mentally-retarded children.

\section{SUGGESTIONS}

With cognizance of all these findings, the writer ventures to offer these recommendations to all who may be interested in the welfare of mentally-handicapped children. According to $\mathrm{Wll} \mathrm{e}^{(1)}$ the fundamental

(1) Wile, Ira s. "sane Social and Psychological Considerations in the Education of the Handicapped." Mentel Hrgiene, Vol. 26, Jan. 1942. p. 99 . 
general recommendations for educating the handicapped should include:

1. The school program should provide adequately for individual growth and development of terms of the facts, processes and ideals essential for wholesome perticipating citizenship.

2. There should be a comprehensive school environment sufficient to permit and foster total personelity development.

3. The teaching personnel should understand the psychology of the school child and appreciating the essential assets and liabilities of school children, should have the capacity to stimulate and to direct their personel education.

4. The school system should have a functional organization that will permit a reasonable degree of cooperation between the home and the school in the interest of the velfare of the children.

5. The board of educationshould foster an administrative organization that ill enable the professional corps to facilitate the best possible foundations of $11 f_{\theta}$ and promote the maxtmom development or intellectual power and practicel akills.

6. The schools should develop broader recreational opportunities for the sharing of social life in the interest of satisfying omotionel noeds and encouraging a balanced personality."

Although these recommendations are advocated for all handicapped children, they are of special significance to the mentelly-retarded child. If the child is detected early enough and is brought up in a school wth these fundamental ideals, he would develop into a competent selfsufficient adult.

The mentally-retarded child should be detected as early as the kindergarten or first grade. The kindergerten teacher because of the highly socialized activity progrem and the close contact she has with her pupils should be treined to detect the potentially retarded child before he meets repeated failure in the early primery grades. If the child does not attend kindergarten, the first grade teacher should be trained to disoover this type of child. There should be preliminary 
scroening by all kindergarten or first grade teachers to provent serious meladjustment by these children in the primary grades, because the child who fails in his school work is al ways an emotional problem.

Fermeld(2) saysi "Every child, elmost without excoption, starts to school eager to learn to "read and write". The first das is a great event. Now he will learnl Then from the start he falls to learn. Day after day he seos other children going ahead with the thing he came to school expecting to do. It is difficult to imagine a more serious case of the blocking of a great desire. Thus the failure to learn is one of the conditions that result in emotional instability.

...The chlld who started to school so eagerly eventually hates or fears the very thing he dreamed of doing when at last he could enter school."

It 1s, therefore, the duty of schools and school personnel to find this child early and help him and to help him to find himself. With complete knowledge of this child, grade standards will give away to individual progress.

To all those who fail to make normel progress remedial help should be given. All chlldren do not reach the reading readiness stage at the same time and administrators must realize more and more that all pupils who enter school together are not all equally ready to read at the same time or at the same rate. The small child suffers a definite break from his informal habits at home to the routine of the school, this plus

(2) Fernald, Grace M.. Remediel Techniques in Banic School subjects. McGraw-Hill Book Company, New York. 1943 p. 7-8. 
failure in his school work needs to be avolded. By giving a group intelIigence test or perhaps individual tests where needed at the time of the entrance to school, the small child who is retarded can be found and placed In a homogenous group until he is ready to receive reading instruction. Enjoyable experiences might furnish opportunity for oral work which in turn might serve as an appreach to reading.

If this small rotarded child is not detected early in his school Iffe, he soon comes to the principal's attention by age-grade reports, attendance records (truancy) or conduct offenses by the time he reaches the Intermediate grades.

According to the Report of the Joint Committee on Maladjustment and Delinquency(3) No one can question the essertion, however that city schools face a problem of gigentic proportions in the attempt to adjust their facilities to the needs and capacitios of the sub-normal-child.

...A fundamental obligation rests upon the school so to modify its requirements as to guerantee a reasonable opportunity for success in school to every pupil. Thenever education fails to do so, it becomes both sturtifying and socially vicious."

That reasonable opportunity for auccess may belong to any retarded child who is a pupil in a good ungraded class or organization, This organization will:

1. Possess the capecity to make very definite contributions to the success of any effort to prevent maladjustment.

2. Retain a low class register in order to stress intelligent

(3) Report and Recommendation of the Jolnt Committoe on Mal adjustment and Delinquency, Board of Education, The City of Nev York. Jan. 1938. p. 76-77. 
child care through a program of group individualized instruction and attempt to reach the individual in a mass.

3. Have constructive supervision that can bring about a type of instruction and guidance that socializes the child and assures the development of healthy attitudes and prevents the destroying of that sense of belonging to a school which is a basis for pupil feeling of security •

4. Integrate through its visiting teacher the efforts of the home, school and the community to make a harpier adjustment for the Individual.

5. Attempt to use the murse, the school or ofty's modical and dental aids to remove many physical defects which may be contributing causes to retardation, and to include the help of the psychologist to reveal the presence of educational lacks and phosical conflicts which often result in a chronic state of dissatisfaction with life in and out of school.

6. Include teachers who possess more accurate and comprehensive Information about the individual child bocause of their training and interest in the welfare of the mentelly-handicapped.

Each school system should have its own bureau of child guidance. An ideal bureau is similar to the one recanmended by the Jolnt Committee (4) on Maladjustment, it consisted of:

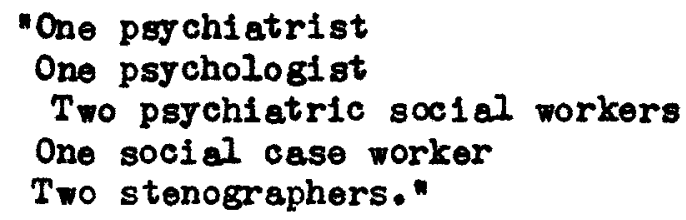

(4) Ibid. p. 83 . 
The efforts of the bureall were concentrated on these four functionss

1. The reeducation of teachers and parents.

2. The rehabilitation of the maladjusted child.

3. The coordination of all agencies which minister to the neods of the child.

4. Detection of maladjusted children in the primary grades."

Every school system should stress the value of good in-service teacher training. This in-service teacher training to be effective should be a continuous process, it should emphesize the aims, objectives and philosophy of the school system, the Improvement of class room guidance. individual and socialized procedures in the classroom, the methods of establishing wholesome teacher pupil relationship, the use of the services of social agencies to prevent and correct meladjustment and the developmont of a sympathotic attitude and understending of the mentelly-handicappod child.

State and city colleges and universities should cooperate with the school boards in their attempt to develop a good plan of in-service training.

The preceding recommendations are not IImited to any elty. Their generality envelops all. To them some specific recommendation suggested by the Works(5) survey for the Loulsville School systems's ungraded class mas be added:

1. There should be a study made of what constitutes a workable curriculum.

(5) Works, George A. Louisv1lie Public School survere A Report on the Public Schools of Louisvilles Kentuckx. Published by the City of Louisville, Ky•, 1943. * 289 . 
2. Wider use of objective material

a. trips

b. visual aids (plctures, films, health posters, museum exhibits.

3. A need of additional reading, matter (this was accomplished in 1945-1946 by nev supervisor of speciel education).

4. Teachers should share in selection of the materials for the class.

5. A need of attractive rooms (because the home environment from wich most of them come is not conductive to the development of high moral or sociel standards. It is nocessery for school to supply whet home lacks.)

6. The ungraded classes should be given the privileges of the regular clesses, should be included in school assemblies, projects. They should participate in as many of the activities of normal children as possible this will help to reduce stigma so frequently accredited to special class placement.

7. The need of superior teachers to enter this field if needs of these children are to be recognized and met satisfactorily.

8. Local provistons for in-service training. (Should have courses at the University of Louisville for exceptionel children.)

9. Glear definition of who should and should not be in such clesses. (This will probably increase the number of classes.)

10. Interest, responsibility and leadership in the supervisory and administrative personnel would help improve the curriculum materials, instruction and schoolroom.

21. There should be provision for overege children to go to junior high."

There is a sincere belief that great strides will be mede in the next fer years in the development of the mentally-retarded child in Louisv1110. A step has already been taken in the appointment of a supervisor of spocial education, a curriculum is to be formed this coming sohool year and other steps are now in progress. If the results obtained in 
this national survey mey prove beneficial in the progress to be made in the administration of the mentally-retarded child in Louisville, then beyond question a progrem based upon some of the recommendations made as the result of this survey would enrich the opportunities of the mentallyhandicapped end enable them to live more edequately in their commity with a higher degree of efficiency and social adjustment. 
BIBLIOGRAPHY 
Boorss

Abel, Theodore $\mathrm{H}_{\bullet}$, and Kinder, Elaine F. The Subnormal Adolescent Girls. New Yorks Columbia University Press. 1942. 214 pp.

American Council on Iducation, Staff of Division on Child Development and Teacher Per sonnel. Helping Teachers Understand Pupils. American Counc1l on Education, Neshington, D. C. $1945.468 \mathrm{pp}$.

Baker, Harry J. Introduction to Exceptionel Ghildren. New York: Macmillan Co.. 1945496 pp.

Burt, Cyril. The Backard Child. New York: D. Appleton-Century Co.. 1937. $694 \mathrm{pp}$.

Californis Textbooks in fducation, Editod by Russell Q. Luter. Living, the Basis for Learning, Santa Barbara California, City school Laboratory. 1942. pp. 189.

Descoeudres, Alice. Pducetion of Mentelly-Defective Children. Pgychological Observations and Practicel Suggestions. D. C. Heath \& Co.. Now York, 1929. 31300 .

Educational Policies Commi ssion. Bducation for AIl Americen Youth. National Bducationel Association of the United States and the American Association of School Administraters. Washington, D. C. 1944. 421 pp.

Featherstone, Wm. B.. The Curriculum of the Speciel Cless. New York: Bureau of Publications, Teachers College, Columbia University. 1932. $153 \mathrm{pp}$.

Ferneld, Grace M. Remedial Techniques in Besic School Subjects, New YorI: MoGrew-Hill Book Co., 1943, 349 pp.

Frampton, Merle Z., and Rowell-Hugh $G$. Fdueation of the Handicapped. world Book Co., Yonker s-on-the-Hudson, New York. 1940, 375 pp.

Heck, A. 0. The Educetion of Exceptionel Children. New York, Mc-Graw-Hill Co.. 1940 .

Hilloboo, Cuy L. Finding and Toaching Atypicel Children. Bureau of Publications, Teachers College Columbia University, New York. 1930. 139 pp.

Ingram. Christine P. Education of the Slov-Learning Child. Workd Book Co., Yonkers-on-liudson, New York: 1935. 419 pp.

Inskeep, Annie D. Teaching Dull and Retarded Children. Now York: Macmillan Co., 1926, $455 \mathrm{pp}$.

Irwin, mizaboth A. and Marks, Louis A.. Pitting the School to the Child An Experiment in Public Education. Now York, MacMillan Co., 1924. $339 \mathrm{pp}$. 
Rivlin, Harry N. meyclopedia of Modern nducation, New Yorks Philosophical Library of New York., 1943. 900 pp.

Tredgold, A. F. Mentel Deficlency. Wm. Wood and Co., New York. 1928. $556 \mathrm{pp}$.

Wallin, John 8. Clinicel and Abnormal Pgychologr. Houghton Miffin Co.. Now York, 1927. 629 pp.

Wall in, John $E .$, The Education of Handicapped Children. Boston: HoughtonMiffin Co.. 1924. 394 pp.

Wipple, Hel on D. Making Citizens of the Mentally-Limited. Bloomington, IIlinois: Public School Publishing Co.., 1927. 374 pp.

White House Conference on Child Health and Protection, Speciel Education, The Hendicapped and the Gifted. New York: The Century Co., 1931

COURSES OF STUDY, PAMPHLRTS AND SURVEYS

Denver, Colorado, Course of Study in Arithmetic and Reeding for the Slov-Learning in the Public Schools. Board of Bducation, Denver. Colorado, 1930. $209 \mathrm{pp}$.

Bxceptionel Children and Public School Policy. Yale University Press, Nev Haven, Connecticut. 1921. $66 \mathrm{pp}$.

Fects About Divisions of Spociel Education. In Baltimore Public schools. Board of Bducation, Beltimore, Md. $1935.39 \mathrm{pp}$.

Gates-Pritohard. Teaching Regaing to Slow-Learnins Pupils. Buresu of Publications, Teachers College Columbia University. New York, 1942. $65 \mathrm{pp}$.

Hov to Fill the Gap Between Special Classes for Mentally-Defective Children and Institutiong. Massachusetts Society for Mental Hygiene, Boston. 1926. 8 pp.

Louisville Public School Survere a Report on the Public Schools of Louisville. Kentuck. Survey made by Dr. Goorgo A. Works. Published by the C1ty of Louisville, Kentucky, 1943. pp. 479.

Schools and Clesses for Ixceptionel Children. The Child With a Problem. Los Ingeles City School Publication. No. 315. 1938. 24 pp.

Study of the Work of Non-Telented Children. Board of Education, Clevelend, Ohio, 1936, 16 pp. 
PUBLIC DOCULANS

Board of Bducation of the City of New York. Report and Recomendations of the Joint Committee on Mel sdiustment and Delinguency. Januery. 1938. Board of Education, Nov York City, pp. 127.

Cenadian Council on Child Welfare, Speciel Training for School Age Children in Noed of Special Care. Ottara, Canada. 1927.

Federal Security Agency, Our Schools in the Post-Fer World. Washington, U. S. Qovernment Printing Office, 1944 pp. 40.

United States Department of the Interior, Office of acation. Clinical Organization for Child Guidancedithin the Schools. Bulletin No. 15, 1939, 78 pp. O. S. Printing Office, Neshington, D. C.

United States Department of Interfor, Office of aducation. Opportunities for the Preperation of Teachers of Fxceptionel Children. U. S. Government Printing Office. Nesnington, D. C. No. 17, 1938 pp. 57

United States Department of Interior, Office of Dducetion. Guide to Gurriculum Ad justment for Montellr-Reterded Children. U. S. Government Printing of fice. Teshington, D. C. No. 11. 1936. pp. 37.

United States Department of Labor, Children's Bureau, Controling Juvenile Delinquencr. U. S. Government Printing Office, Mashington, D. C. 1943.

\section{FHRIODICALS}

Anderson, u. L. The Meaning of Education for the Mentally-Retarded. Americon Journel of Mental Defielency. Vol. 46., Jan. 1941. pp. 6-16.

Bender, Laurotta, "Nouropsychiatric Contributions to the Mental Hygiene Problems of the Ixceptional Child." Mentel Hratene, Vol. 26, Oct. 1942. pp. 617-622.

Bryne, May E., "Gurriculum Planning for Exceptional children." Journol of Bxeptional Children. Vol ., 12, Mar 1946. p 231-234.

Fourecre, M. H. "Improving the Relationship Between the Community and the Class for Mentally-Retarded." Journel of Exceptionel Children. Vol. 12. Jan, 1946.

Glueck, E. T. "Mental Retardation and Juvenile Delinquency." Mentel Hrgiene. Vol. 29. October, 1935. pp. 549-572.

Harms - I. "Social Implications of the Mentelly Disadvantaged Child," School and Society. Vol. 63, April 27, 1946, p 291-293. 
Hockett, John H. "The Mentally-Handicapped." Review of Educational Research. Vol. 14, Juno, 1944.

Hughes, Byron 0. "Iducational Problems of Slov-Learning Children." University of ulchisen School of nducation Bulletin. Vol. 17, No. 3., Dec. 1945.

Hughes, Byron 0. "Educationel Problems of slow-Learning Children. Educationel Digest, Vol. 2, Fob., 1946. pp 27-29.

McKeon, Rebocca M., "Mentally-Reterded Boys in Wertime." Mental Hygiene. Vol. 30, Jan, 1946. pp. 47-55.

McKenzie, C., "Blow Learners," Ner York T1mes Megazine. May 21. 1944. p. 29 .

Martens, Elise H., "Ner Tasks in the Education of Exceptional Children." Netional Educationel Journel-Vol. 35, May 1946. p. 239.

Patej, Henry C., "The Teacher as a General Practitioner in Mental Hygiene." Eental Hrglene, Vol. 24, Det. 1940 p p.600-613.

Stevens, G. D. "An Evaluation of Some Methods of Organization of Classes for the Mental ly-Retardod Adolescent." Vol. 31. Mducationel Administration and Supervision. April. 1945.

Stevens, G. D., "sugsested Criteria far the Selection of Items for a Cumulative Case study Record for the Mentally-Retarded." Journel of Bducationsl Research. Vol. 31, Nov ., 1945.

Hle. Ire S., "Some Social and Psychological Considerations in the Education of the Handicappod." Mental Hrgiene, Vol. 26, Jan. 1942. pp. 92-99.

Zehrobsky, Mary. "Bducating Handicapped Ghildren in the Public schools In Illinois." The Social Service Revier. Vol. 20, June, 1946. pp. 180-197.

Segregation versus Non-Segragation of Exceptional Children." Panel report Journal of Exceptionel Children. May, 1946. Vol. 12, 235-240.

ISpecial Education is a Part of Americen Triumphant Course Toward a Fuller Life for All. Journel of Exceptionel Children. Dec., 1943. vol. 10.

"That Changes in Iducation Nould Bring About Better Mental Health." Understending the Child. Nol, Vol. 15, Jan. 1946. pp. 11-14. 
A PPRNDIX 
The following lotter and questionnaire was sent to the Directors of Research or Superintendent of schools in the forty cities. 


\section{8 masterm Parkway Louisville, $\mathrm{Ky}$. July 5, 1946.}

Dear sir.

I am making a "study of the Trends and Issues in the Administration of Classes for the Mentelly-Retarded Child in the Elementary School."

The questionnelre, which I am inclosing contains many points vital to the survey. I sincerely hope that you can help me to acquire some of this information. I would appreciate It if you will answer and return the questionnaire in the stamped self-addressed inclosed envelope.

I shal I be glad to send you the results of my findings, if you request it.

Yours very truly. 
As a roeult of my roading. I have found that the most provalent and socepted definitions of mentelly-handicapped or subnormal ohildren are those preposed by Christine $P$. Ingram in The Eduoation of the Slow-Learning Child.

They are:

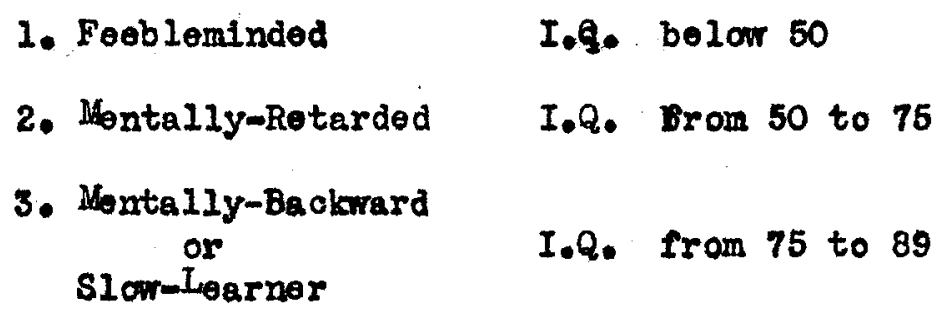

With these definitions in mind. I would like to heve your help on the following questionnaire.

$* * * * * * * * * * * * * * *$

\section{MEMBRSHIP TYPES OF PUPILS ADHITTED}

Pleage oheok what conctituter the enroliment of your ungraded or apeoial olasson.

1. Only the montally-rotarded with I.Q. of 50 to 75.

2. Only the mentally-backward with $I_{0} Q$. of 75 to 89 .

3. Only the reeble-minded with I.Q. below 50.

4. Only the emotionally unatable, behavior problems.

6. Only the eduoationally-backward, retarded in one or more vubjeot. but appearing normal mentally.

6. Thi mentally-retarded and the mentally-baokward

7. The montally-retarded and the educationally-backward.

8. The mentally-retarded and the emotionally unstable.

9. AII groups 1-8 combined.

10. Pleave atate any other plan of membership that you may use. 
II. MEMBERSHIP, METHODS OF SELECTION

Ploase ohook the mothod used in seleoting pupile for placoment in ungraded or spocial classes.

1. By intelligenco tosts (Binet or similar)

2. By age-grado 11ate

3. If by age-grade lists, by how many years retarded.

4. By psychologiot's reconnendation

B. Behavior problems that upeet the normal classroom-misfits in a regular class.

6. Recomendation of his last normal-class teaohor.

7. Recommendation from all his previous teachers, who believo child would profit by special

olass instruotion.'

8. Plesen otate any other methods.

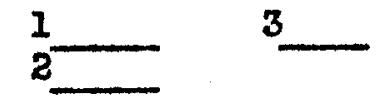

III, YUVBERSHIP, REQUIRED INFORMATION

Please ohook what is known of child before he is admitted to the ungraded or spocial olass.

1. Mantal Ability.

2. Aohlevement from otandard teat.

3. Results of physicdl examination

4. School rocord or history including teacher's otatement regarding habits.

5. Heredity and family history.

6. Environmental conditions.

7. Emotional etatus.

8. Interest and aptitude test.

9. Please list any other information whioh you obtain before admission. 
2. HOUSING

Please cheok the arrangement of the ungraded or epeolal classer under your administration.

1. One class in each elementary sohool.

2. Several classes in each elementary school.

3. One class in cortain schools where needed.

4. Several olesses in certain elementary chools.

5. Spoolal sohool center for ungradod or special olasses.

6. Pupils left in regular classroom.

7. If any other method, please state.

V. QUAIIFICATIONS OF TEACHERS.

Plesse oheck the requirements for teachers of ungraded or special olacses.

1. Are the teachers epecially-trained to eare for these ohildren?

2. Does the sohool system have classes for in-service training of these teachere?

3. Are these teachers required to take courses in psyohometries that they may bo ablo to determine the ohild's placement?

4. Does the state require a certain number of hours of speciallzation?

5. If so, please give the number of hours that are required

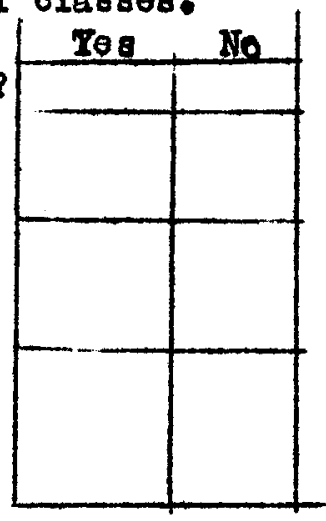

By state hours

By oity hourg

6. Please list any other qualifications.

VI. SUPERVISION

Please ohook these details of supervision of ungraded or special classer.

1. Doos the sohool aystem have a apecially-trained Yos No supervis or?

2. Does the supervisor have any other duties than the supervision of ungraded or spoóial elassea? 
3. If so, please list duties.

4. Does the oupervisor have complete harge of the soloction of instruotional materials and supplies?

Yes No

5. If not, who assiste hor?

6. Does the supervisor have any part in the nomination and selection of teachers of ungraded or spocial -las8es?

\section{CURRICULUM}

Ploase ohock tho following:

1. Does the supervisor with the teachers of special or ungradod lasses construot the ourriculum?

2. It thero a dofinito plan of currioulum?

3. Is the ourriculum only tho regular course of study taken at a slower paces

4. Is learning aoquired through a program of uaried topioal activity units?

5. Aro skills acquirod

A. Incidontally through tho activity program

B. By drill work at opecific timos

C. By planned work with the activities

6. Is the hild made aware of tho facilitios of the eity which aro his to use now and 28 an aduit? (For examplo, T.B. olinic, social agenoior)

7. Do toachers koep record of booka and materials used?

8. Are teachera givon froedom in selooting these materialo?

9. If not, who soleots the matorials?

10. Does the school have aocoss to a reoognized, ostablishod clinio (paychologist, psyohiatrist and social worker) to aid in diagnosing montal retardation, behavior maladjustment and edueational retardation?

11. Is there any proviaion made for the young-dull ohild who oannot adjust in kindergarten? 
CURRICULUM (dontinued)

12. Doos the ourrioulum include shop-work?

Yes No

13. How much timo is derotod woekly to shop-work? hours

14. How much time is dovoted daily to handwork?

15. Is there a guidance plan to help the child to soloot omploymont after school yoars?

16. Is thero any plan to follow-up the ohtld after he loaves tho ungradod or spoolal olass?

17. If 80, please givo details hours

Yas No

Yes No

18. Aro any of these instructional mothods used?

12. A. Exoursions to placos of interest

B. Motion pictures and other visual aids

C. Construction of friozes

Displays

models

charts

19. Aro industrios and amall shops visitod by the class?

20. Aro roprosontatives of various ronations invitod to the olass?

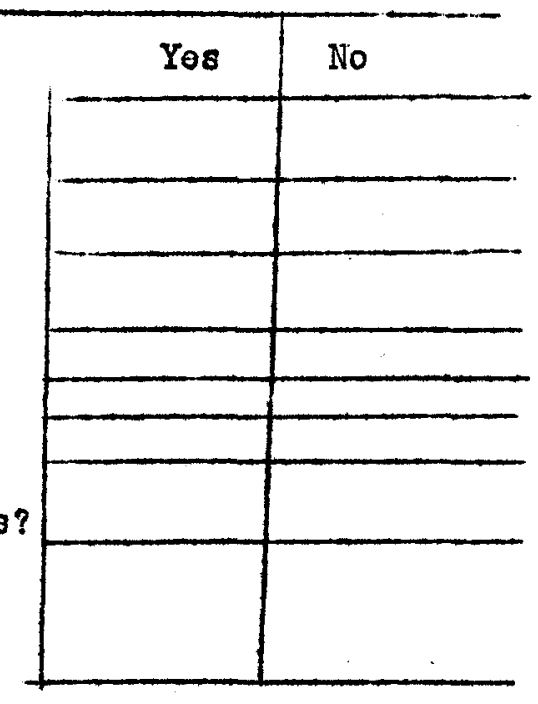

VIII. MISCELIANEOUS. PloQ80 chock.

1. Are teachors required to visit oa oh home to understand the homo baokground of each ohild?

Yos No

2. If not, is a visiting toachor usod?

Yos No

is a social worker of an agency used?

Yes No

3. What is tho maximum number of pupils per toacher? pupils

4. What is tho basis for transfor from ungraded or spocial class to rogular olass?

AEO years

Roiading Lovel

Sizo 